\title{
Comparison of wear and rolling contact fatigue behaviours of bainitic and pearlitic rails under various rolling-sliding conditions
}

\author{
Y. Hu ${ }^{\text {a, }}$, L.C. Guo ${ }^{\text {a }}$, M. Maiorino ${ }^{c}$, J.P. Liu ${ }^{\text {d }}$, H.H. Ding ${ }^{\mathrm{a}}$, R. Lewis ${ }^{\mathrm{b}}$, E. Meli ${ }^{\mathrm{c}}$, A. Rindi ${ }^{\mathrm{c}}$, Q. \\ Y. Liu ${ }^{a}$, W.J. Wang ${ }^{\text {a,* }}$ \\ ${ }^{a}$ Tribology Research Institute, State Key Laboratory of Traction Power, Southwest Jiaotong University, Chengdu, 610031, China \\ ${ }^{\mathrm{b}}$ Department of Mechanical Engineering, The University of Sheffield, Mappin Street, Sheffield, S1 3JD, UK \\ ${ }^{\mathrm{c}}$ Department of Industrial Engineering, University of Florence, Via S. Marta 3, 50139, Firenze, Italy \\ ${ }^{\mathrm{d}}$ Metals and Chemistry Research Institute, China Academy of Railway Sciences, Beijing, 100081, China
}

\section{A R T I C L E I N F O}

\section{Keywords:}

Bainitic and pearlitic rails

Wear regime

RCF evolution

Fatigue crack

\begin{abstract}
A B S T R A C T
Rolling-sliding wear experiments were performed to investigate the wear and rolling contact fatigue (RCF) behaviours of a premium pearlitic rail (PH), a carbon-free bainitic rail (BH) and two standard pearlitic rails (U71Mn and U75V). The wear regime and RCF damage evolution of the $\mathrm{PH}$ and $\mathrm{BH}$ materials in terms of $T \gamma / A$ (i.e. creepages and contact pressures) were compared and analyzed. The high-hardness BH steel presented a wear resistance similar to U71Mn and U75V rail materials, whereas lower wear rate was shown by the PH steel. Concerning the RCF performance, the damage of $\mathrm{BH}$ steel (comparable to U75V) was more severe than that of $\mathrm{PH}$ steel (comparable to U71Mn). Finally, with the increase in creepages and pressures, the wear and RCF damage of both $\mathrm{PH}$ and $\mathrm{BH}$ steels increased. These information could provide a guide in choosing rail materials and in development of bainitic rails.
\end{abstract}

\section{Introduction}

Rail repair and replacement have always been a major proportion of railway operating costs. Wear damage, typified by side wear of the railgauge and corrugation of the rail head, and RCF damage, dominated by gauge corner cracking, head checks, squats, shelling, etc. [1-3], are the two main factors that could accelerate the degradation and shorten the service life of rails. One of the most effective ways to reduce wear and $\mathrm{RCF}$ and extend rail service life is to develop and use premium rails with improved tribology properties and RCF resistance.

The most commonly-used rail materials in most countries have been pearlitic steels, which are composed of alternative ferrite and cementite lamellae. In recent years, advanced rail materials possessing excellent mechanical properties have been developed by increasing the carbon content up to even hypereutectoid levels and refining the lamellar structure through alloying or heat treatment, as shown in Table 1 [4-6]. It can be seen that the carbon content of European rail materials has increased from $0.40 w t \% \sim 0.60 w t \%$ in $\mathrm{R} 200$ rail to $0.9 w t \% \sim 1.0 w t \%$ in the advanced rail grade 400UHC. The hardness has also increased from $200-240 \mathrm{HB}$ to nearly $400 \mathrm{HB}$. Meanwhile, the mechanical properties of the advanced rail materials have been greatly improved, for example, the tensile strength of 400UHC grade rail has been enhanced up to 1240 MPa. Besides, laboratory research and field tests presented excellent wear resistance and low RCF crack growth rate for the advanced R350HT and 400UHC rails [4,7-11]. The standard U71Mn and U75V rails have been widely used and researched in Chinese railway networks $[12,13]$, whereas few investigations on the wear and RCF performance of the Chinese advanced rail materials have been performed.

It is well known that the strength of pearlitic rail steels has reached a limit [14]. Besides, an increase in carbon content would affect the toughness and weldability of rail materials [5]. For example, compared with the hypoeutectoid R200 rail, the elongation of the hypereutectoid 400UHC rail reduces down to $9 \%$ (Table 1 ). Therefore, there is a strong need for other alternative materials. Bainitic steel, providing both high strength and excellent ductility, has been considered to be one of the most promising candidates.

There are many structures of bainitic steels. According to the transformation temperature, they can be divided into upper bainite and lower bainite. Lower bainite is widely used and studied for rail materials due to its excellent properties in terms of strength, toughness and RCF

\footnotetext{
* Corresponding author.

E-mail address: wwj527@swjtu.cn (W.J. Wang).
} 
Table 1

European and Chinese rail steels and their properties [4-6].

\begin{tabular}{|c|c|c|c|c|c|c|c|}
\hline Steel grade category & Rail grade & Micro-structure & $\mathrm{C} / w t \%$ & $\mathrm{R}_{\mathrm{m}, \min } / \mathrm{MPa}$ & $\mathrm{A}_{5, \min } / \%$ & Hardness/BHN & Improvement ratio of wear resistance [5] \\
\hline European soft & R200 [6] & Pearlite & $0.40-0.60$ & 680 & 14 & $200-240$ & 1 \\
\hline \multirow[t]{2}{*}{ European standard } & $\mathrm{R} 220$ & Pearlite & $0.50-0.60$ & 770 & 12 & $220-260$ & 1.7 \\
\hline & R260 & Pearlite & $0.62-0.80$ & 880 & 10 & $260-300$ & 3 \\
\hline \multirow[t]{4}{*}{ European advanced } & $\mathrm{R} 320 \mathrm{Cr}$ & Pearlite & $0.60-0.80$ & 1080 & 9 & $320-360$ & 5 \\
\hline & R350HT & Pearlite & $0.72-0.80$ & 1175 & 9 & $350-390$ & 8.5 \\
\hline & 370LHT & Pearlite & $0.70-0.82$ & 1175 & 9 & $>370$ & / \\
\hline & 400UHC & Pearlite & $0.90-1.00$ & 1240 & 9 & $>380$ & / \\
\hline \multirow[t]{2}{*}{ Chinese standard } & U71Mn & Pearlite & $0.65-0.75$ & 880 & 9 & $260-300$ & / \\
\hline & U75V & Pearlite & $0.71-0.80$ & 980 & 9 & $280-320$ & / \\
\hline \multirow[t]{2}{*}{ Chinese advanced } & $\mathrm{U} 78 \mathrm{CrVH}$ & Pearlite & $0.75-0.8$ & 1366 & 12 & 385 & / \\
\hline & U75VH & Pearlite & $0.72-0.77$ & 1274 & 14.5 & 354 & / \\
\hline
\end{tabular}

resistance [14]. According to the phase composition, it can be classified into carbide bainite and carbide-free bainite. Carbide-free bainitic steel has a special structure with bainitic ferrite and retained austenite films. General investigations of the wear performance of lower bainitic steels showed that the carbide-free bainitic steels perform well [15-18]. More precisely, according to carbon content, bainitic steels can be classified into ultra-low carbon bainite, low carbon bainite, medium carbon bainite, and high carbon bainite. Most of the studies showed poor wear resistance of high carbon bainitic steels due to their special microstructures whereas positive results for low and medium carbon bainitic steel could be observed [19-22]. Currently, the bainitic rails used in Japan, Switzerland, France and Czech Republic are carbide-free bainitic steels (lower bainite) with a carbon content of $0.2 w t \% \sim 0.3 w t \%$ [14-18].

With the extensive application of bainitic steel in railway networks, one key question has arisen for companies and researchers: which rail possesses the better wear and RCF performance, bainitic rail or pearlitic rail? Bainitic rail steels have been generally found to show better resistance to RCF damage than pearlitic rail steels [23-27], focusing on superior flaking resistance, excellent weldability and high low cycle fatigue life (about twice that of pearlitic rail). However, the above research results [23-27] were mainly from fatigue tests. Under the rolling-sliding contact at the wheel/rail interface, the anti-RCF property of bainitic rails may show different characteristics because of the competition and restriction effects of wear and RCF. For example, severe spalling and transverse cracks have been found on bainitic rails and crossings in the field [28].

Similarly, even though extensive sliding and rolling wear investigations on bainitic and pearlitic rails have been carried out during past decades, there is no common conclusion on whose wear performance is better. The results of previous studies [27,29-37] are provided in Appendix A. It indicates that the good wear resistance of bainitic rail steels partially depends on the rail grades (hardness) of the pearlitic rail steel considered in the comparison. For standard pearlitic rails, the bainitic rails generally presented good wear resistance [29,34,35], while it was poor if compared to advanced pearlitic rails [33,35]. Besides, work hardening is a key consideration in comparison of pearlitic and bainitic rail steels. The low work hardening for bainitic rails was believed to be responsible for their poor wear response [32,35,38]. Moreover, contact conditions also play a significant role in the wear response of rail materials [39-41], where the two most important factors are creepage and contact pressure (influenced by axle load and profiles).

For these reasons, a definitive conclusion on the characteristics of the bainitic steels needs a more systematic investigation of the wear, work hardening and RCF performance of standard pearlitic rails, advanced pearlitic rails and bainitic rails under various loading conditions.

A fear will arise that introducing harder pearlitic and bainitic rails will have a detrimental influence on the matched wheels. For this issue, different results have been found in previous studies: At first, it was believed that using hard rail steels would give an increase in wheel wear loss [42,43]; whereas, a full-scale study [8] showed that the harder R350HT rail reduced rail wear with a simultaneous reduction in wheel wear, indicating that the high-hardness rail steel was beneficial to the matched wheel steel. Furthermore, Lewis et al. [44] performed an investigation across all scales experiments in both laboratory and field, and found that the wheel wear did increase with rail hardness, but the total wear reduced, thereby, they believed this fear was unfounded.

In this study, a series of rolling-sliding wear experiments were carried out to investigate the wear, work hardening and RCF behaviours of two kinds of Chinese standard rails (U71Mn and U75V), a newly developed premium pearlitic rail and a new carbon-free bainitic rail. Besides, the wheel and total wear responses were analyzed when using different rail materials. Specifically, the wear regime and RCF damage evolution of the premium pearlitic rail and the bainitic rail under different creepages and pressures were compared and analyzed.

\section{Experimental procedure}

\subsection{Materials and processing}

Four types of rail materials (U71Mn, U75V, PH and BH) and one kind of wheel material (C-class) were used in this study. Their chemical compositions and hardness' are summarized in Table 2. U71Mn and U75V are standard pearlitic rail steels. The rail steels marked $\mathrm{PH}$ and $\mathrm{BH}$ are a newly developed pearlitic steel and a new carbide-free bainitic steel, respectively. The letter " $\mathrm{H}$ " indicates that the rail steel underwent some special heat treatment. Compared with the conventional rail steels (U71Mn and U75V), the PH with high carbon content of $0.90 w t \%$ $0.95 w t \%$ possesses a relatively high hardness of $405 \mathrm{HV}_{0.5}$. However, the bainitic steel is even harder than the $\mathrm{PH}$ steel due to its unique structure.

The microstructure images of wheel and rail materials, taken by

Table 2

Chemical compositions and mechanical properties of wheel and rail discs.

\begin{tabular}{|c|c|c|c|c|c|c|c|}
\hline \multirow[t]{2}{*}{ Component } & \multirow[t]{2}{*}{ Grade } & \multicolumn{5}{|c|}{ Chemical composition ( $w t \%$ ) } & \multirow[t]{2}{*}{ Bulk hardness $/ \mathrm{HV}_{0.5}$} \\
\hline & & $\mathrm{C}$ & $\mathrm{Si}$ & Mn & $\mathrm{P}$ & $\mathrm{S}$ & \\
\hline Wheel & C-class & $0.67-0.77$ & $0.15-1.00$ & $0.60-0.90$ & 0.030 & $0.005-0.040$ & $354 \pm 10$ \\
\hline \multirow[t]{4}{*}{ Rail } & U71Mn & $0.65-0.75$ & $0.15-0.35$ & $1.10-1.40$ & $\leq 0.030$ & $\leq 0.030$ & $278 \pm 12$ \\
\hline & U75V & $0.71-0.80$ & $0.50-0.80$ & $0.70-1.05$ & $\leq 0.030$ & $\leq 0.030$ & $303 \pm 14$ \\
\hline & PG5 (PH) & $0.90-0.95$ & $0.48-0.52$ & $0.94-1.02$ & $0.01-0.014$ & $0.04-0.07$ & $405 \pm 17$ \\
\hline & U22SiMn (BH) & $0.20-0.26$ & $1.30-1.45$ & $2.00-2.10$ & $\leq 0.025$ & $\leq 0.025$ & $451 \pm 10$ \\
\hline
\end{tabular}



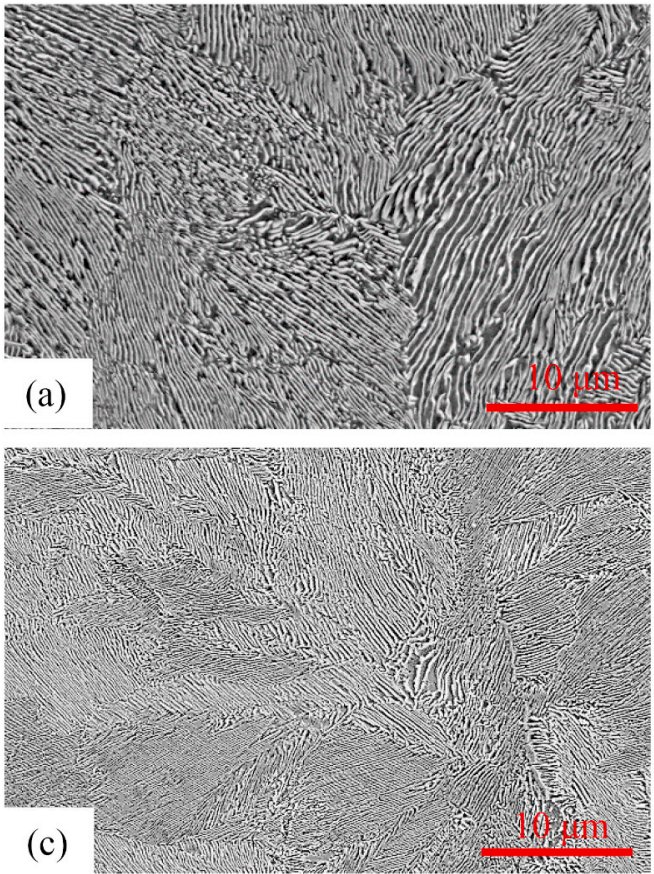
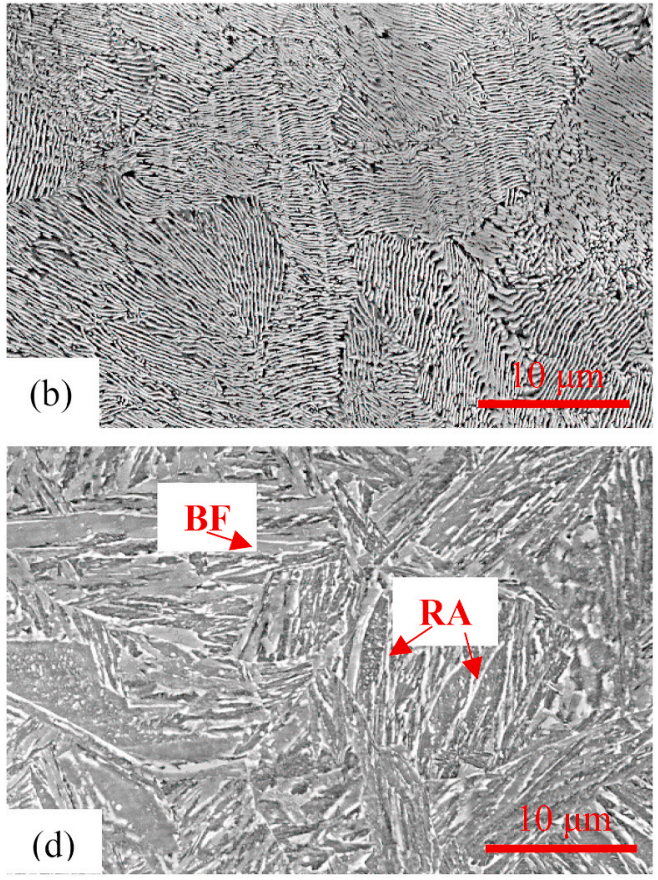

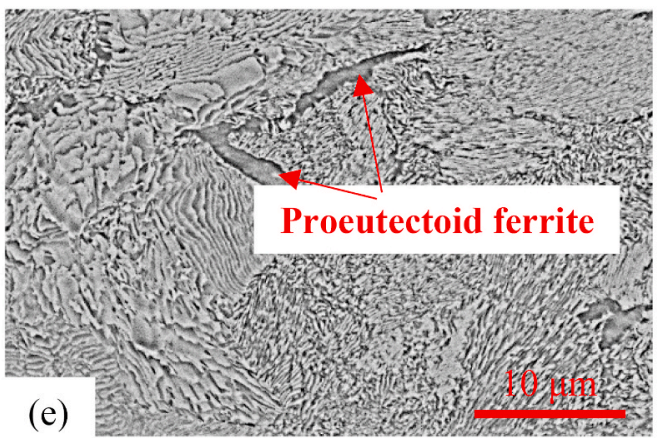

Fig. 1. SEM micrographs of wheel and rail materials: (a) U71Mn; (b) U75V; (c) PH; (d) BH; (e) C-class.
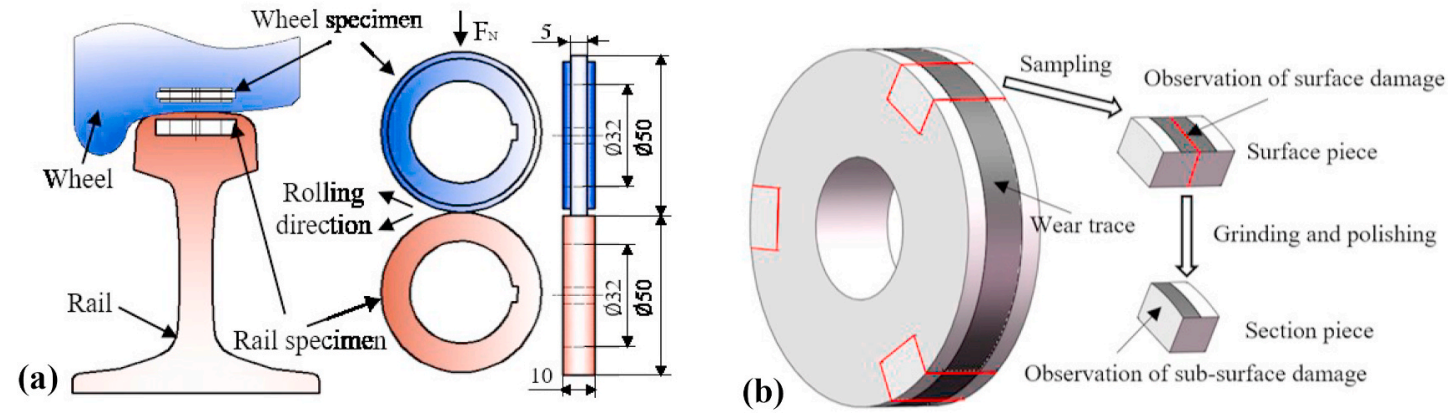

Fig. 2. (a) Sampling position and size of wheel and rail specimens; (b) sampling position of cross-sectional samples.

scanning electronic microscope (SEM), are presented in Fig. 1. The wheel material, C-class steel, has ferrite-pearlite microstructure which is composed of lamellar pearlite and a little proeutectoid ferrite (Fig. 1e). U71Mn, U75V and PH rail steels behave as almost fully pearlitic microstructures with alternating ferrite and cementite lamellae (Fig. 1a-c). It is well known that the average pearlite lamellar spacing $(S p)$ plays a vital role in the mechanical properties of pearlitic steels. The statistical results for $S p$, measured by means of the circular line method $(S p=0.5 \mathrm{~L} /$ $\mathrm{N}$, where $L$ is length of the circle and $N$ is number of intersections between the circular line and the lamellae) [45], show a decreasing trend in U71Mn, U75V and PH rail materials $(238.4 \pm 51 \mathrm{~nm}, 202.4 \pm 49 \mathrm{~nm}$ and $96.8 \pm 28 \mathrm{~nm}$, respectively). The BH rail steel presents a typical carbide-free bainitic microstructure, consisting of bainitic ferrite (BF) plates, the "film-like" retained austenite (RA) and blocky RA (Fig. 1d).

The sampling positions and detailed sizes of the wheel and rail samples are presented in Fig. 2a. Wheel and rail samples were cut from the treads of C-class wheels and the head of the four types of rails, respectively. The diameter was $50 \mathrm{~mm}$ for both the wheel and rail samples, and the contact width was $5 \mathrm{~mm}$. 


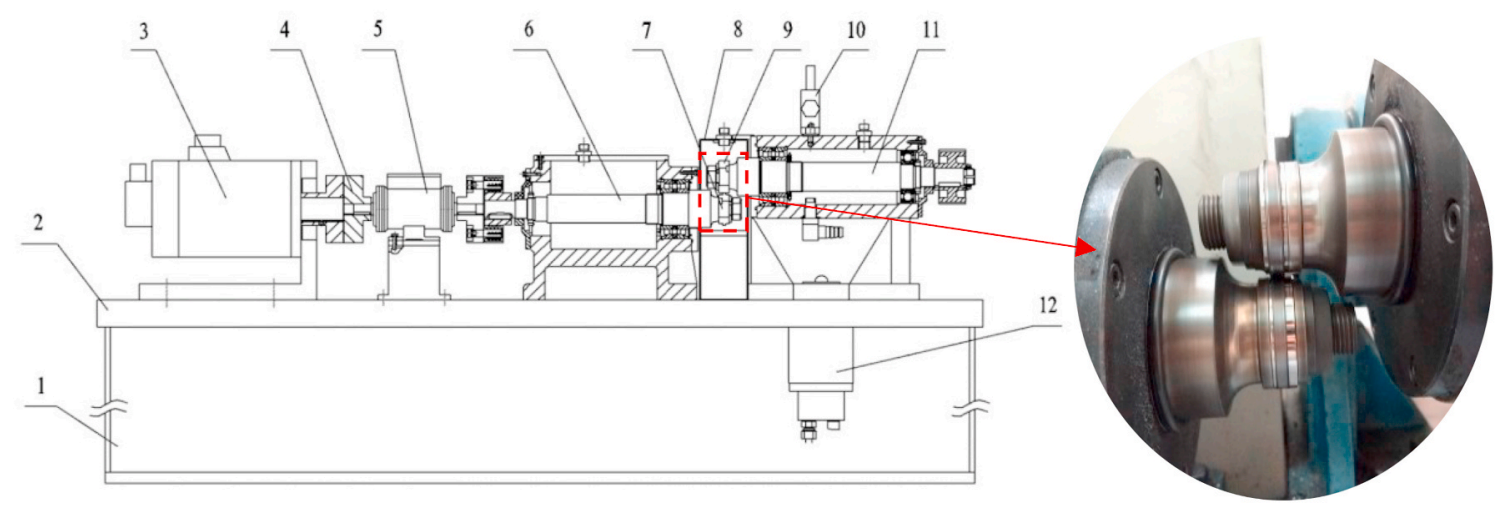

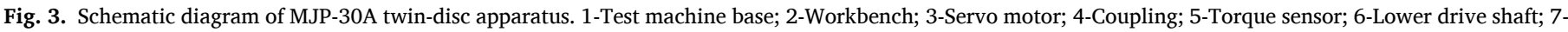
lower disc; 8-Oil box; 9-Upper disc; 10-Vibration sensor; 11- Upper drive shaft; 12-Hydraulic device.

Table 3

Summary of test conditions.

\begin{tabular}{|c|c|c|c|c|c|c|c|}
\hline Test number & Rail grade & Wheel grade & Hardness ratio/ $\left(\mathrm{H}_{\mathrm{R}} / \mathrm{H}_{\mathrm{W}}\right)$ & Creepage/\% & Contact pressure/MPa & Speed/(rpm) & Cycles/N \\
\hline 1 & U71Mn & C-class & 0.783 & 1 & 1500 & 500 & 25,000 \\
\hline 2 & U75V & C-class & 0.854 & 1 & 1500 & 500 & 25,000 \\
\hline 3 & $\mathrm{PH}$ & C-class & 1.144 & 1 & 1500 & 500 & 25,000 \\
\hline 4 & $\mathrm{BH}$ & C-class & 1.273 & 1 & 1500 & 500 & 25,000 \\
\hline 5 & PH & C-class & 1.144 & 1 & 800 & 500 & 25,000 \\
\hline 6 & $\mathrm{BH}$ & C-class & 1.273 & 1 & 800 & 500 & 25,000 \\
\hline 7 & $\mathrm{PH}$ & C-class & 1.144 & 1 & 1100 & 500 & 25,000 \\
\hline 8 & $\mathrm{BH}$ & C-class & 1.273 & 1 & 1100 & 500 & 25,000 \\
\hline 9 & $\mathrm{PH}$ & C-class & 1.144 & 0.2 & 1500 & 500 & 25,000 \\
\hline 10 & BH & C-class & 1.273 & 0.2 & 1500 & 500 & 25,000 \\
\hline 11 & PH & C-class & 1.144 & 5 & 1500 & 500 & 25,000 \\
\hline 12 & $\mathrm{BH}$ & C-class & 1.273 & 5 & 1500 & 500 & 25,000 \\
\hline
\end{tabular}
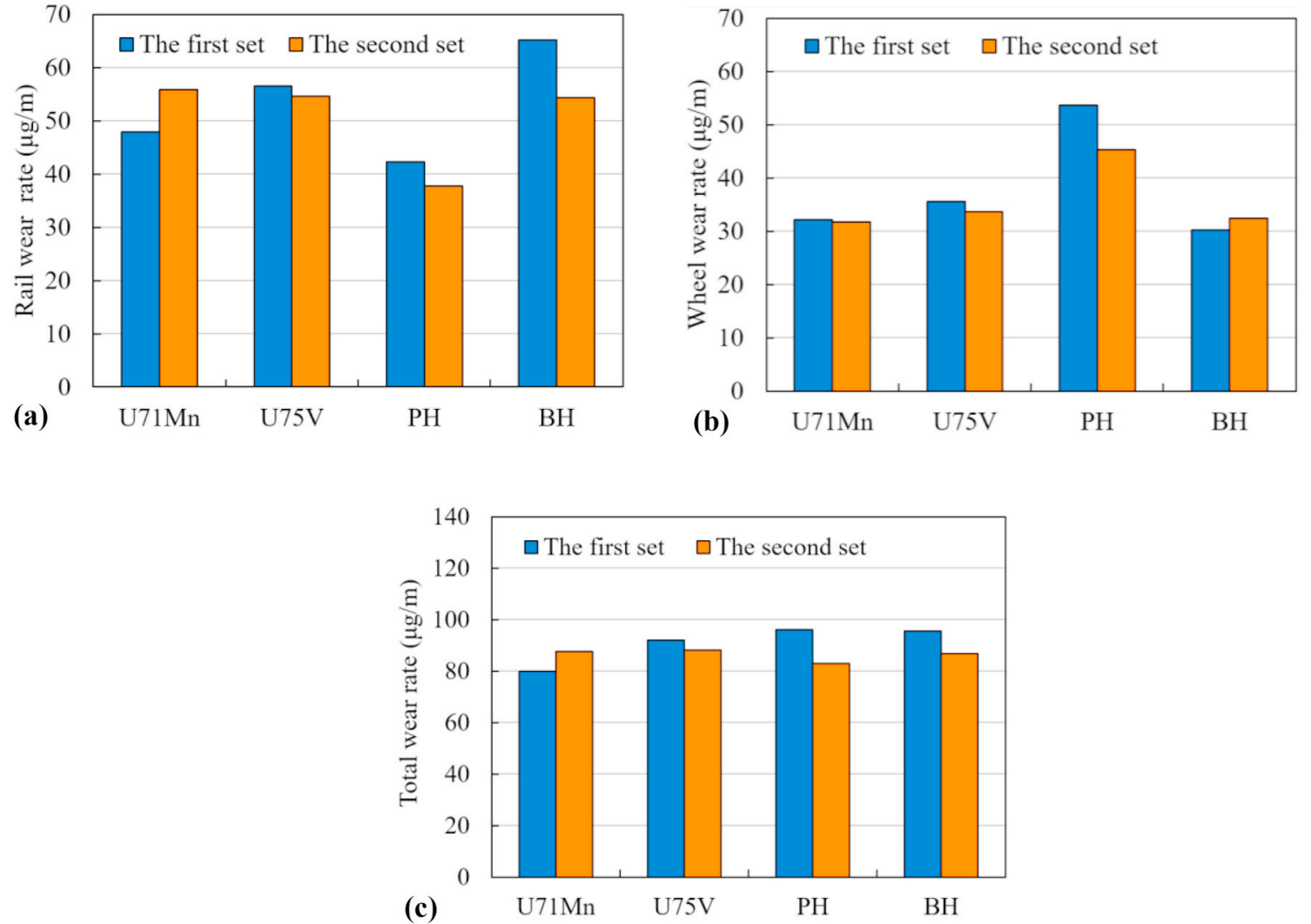

Fig. 4. Wear rates for different rail materials (1\%, $1500 \mathrm{MPa})$ : (a) rail; (b) wheel; (c) total. 


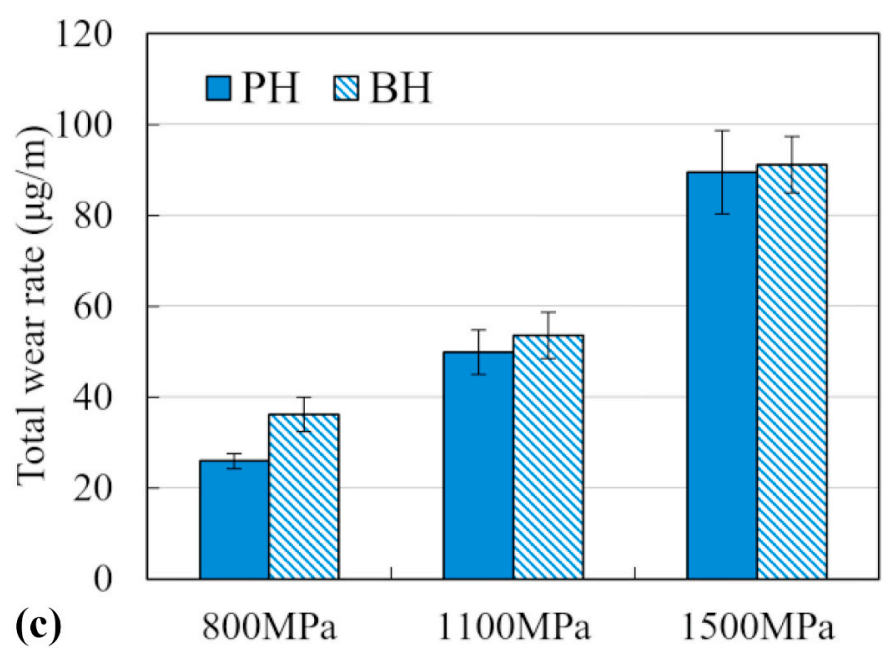

Fig. 5. Wear rates as a function of contact pressure (creepage 1\%): (a) rail; (b) wheel; (c) total.

\subsection{Rolling-sliding experimental details}

As an open system, the wheel-rail interface is subject to environmental conditions and contaminants. This study focused on the influence of different rail materials and rolling-sliding loads on the wear response. In order to avoid the environmental factors affecting the results, all experiments were assumed to be carried out in an ideal dry condition.

The experiments were performed through a twin-disc apparatus (MJP-30A, China), which allows two discs to run against each other with controlled normal and tangential forces to simulate the rolling-sliding contact of wheel and rail, as shown in Fig. 3. These two discs are driven by two independent electric motors. The required creepages can be achieved by adjusting the different rotational speeds of discs.

The test parameters are listed in Table 3. Wear tests for four rail materials were performed under a general rolling-sliding condition (contact pressure $1500 \mathrm{MPa}$, creepage 1\%). In order to compare the wear response of the new $\mathrm{PH}$ and $\mathrm{BH}$ materials in various common conditions, wear tests for $\mathrm{PH}$ and $\mathrm{BH}$ rails were conducted under three creepages $(0.2 \%, 1 \%, 5 \%)$ and three contact pressures (800 MPa, 1100 $\mathrm{MPa}, 1500 \mathrm{MPa}$ ). Each set of test was repeated twice.

The wear loss of wheel and rail discs was calculated by considering the weight difference of the pre-test and post-test discs and measured using an electronic balance (JA4103, accuracy: $\pm 0.0001 \mathrm{~g}$ ). The surface hardness of wheel and rail discs was measured by using a Vickers hardness instrument (MVK-H21, Japan) with $4.9 \mathrm{~N}$ load $\left(\mathrm{HV}_{0.5}\right)$ and $10 \mathrm{~s}$ dwell time. Fig. $2 \mathrm{~b}$ shows the sampling position for metallographic observations of surface damage and sub-surface damage. Each section piece was prepared for microstructure observation by standard metallographic procedures. The surface damage, plastic deformation and fatigue cracks were characterized by using optical microscopy (OLYMPUS BX60 M, Japan) and SEM (JSM-7800FPRIME, Japan). The length and depth of each surface crack were measured using OM equipped with an image analysis software.

\section{Results}

\subsection{Wear rate and hardness}

Fig. 4 presents the wear rates (mass loss $(\mu \mathrm{g})$ per rolling distance $(\mathrm{m})$ ) for different rail materials. Under the same contact condition (creepage $1 \%$, pressure $1500 \mathrm{MPa}$ ), the $\mathrm{PH}$ rail steel exhibits the best wear resistance (Fig. 4a) due to its high bulk hardness, whereas the wear losses of

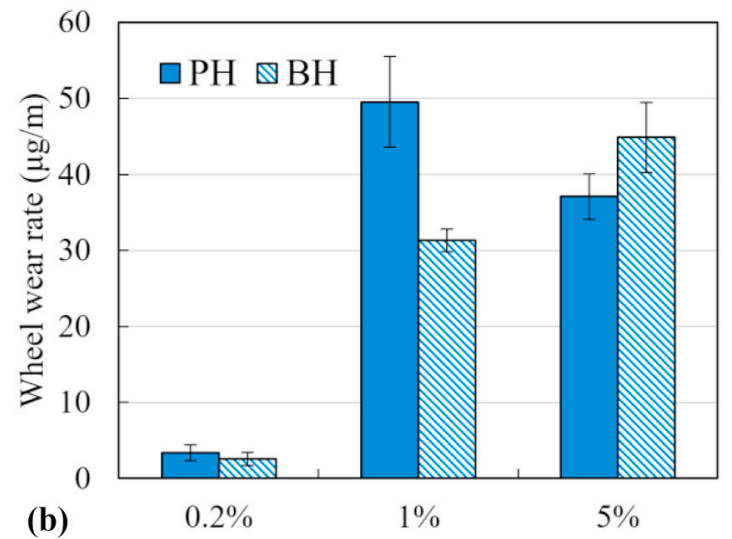

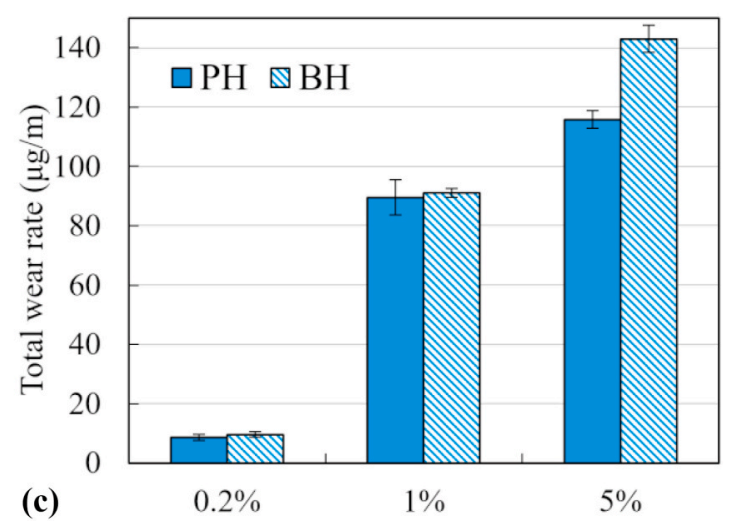

Fig. 6. Wear rates as a function of creepage (pressure $1500 \mathrm{MPa}$ ): (a) rail; (b) wheel; (c) total. 

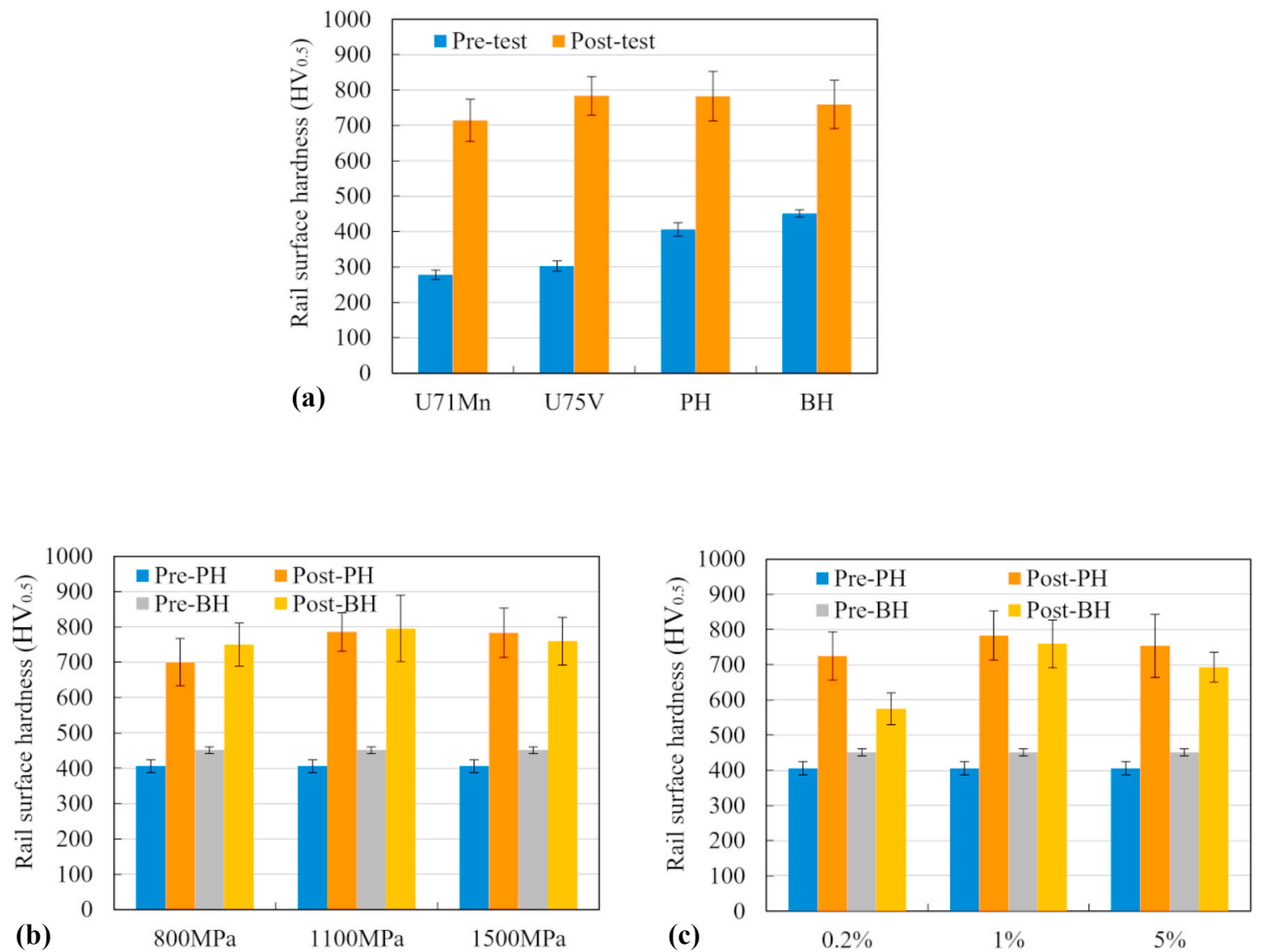

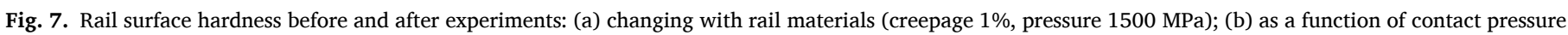
(creepage 1\%); (c) as a function of creepage (pressure $1500 \mathrm{MPa}$ ).
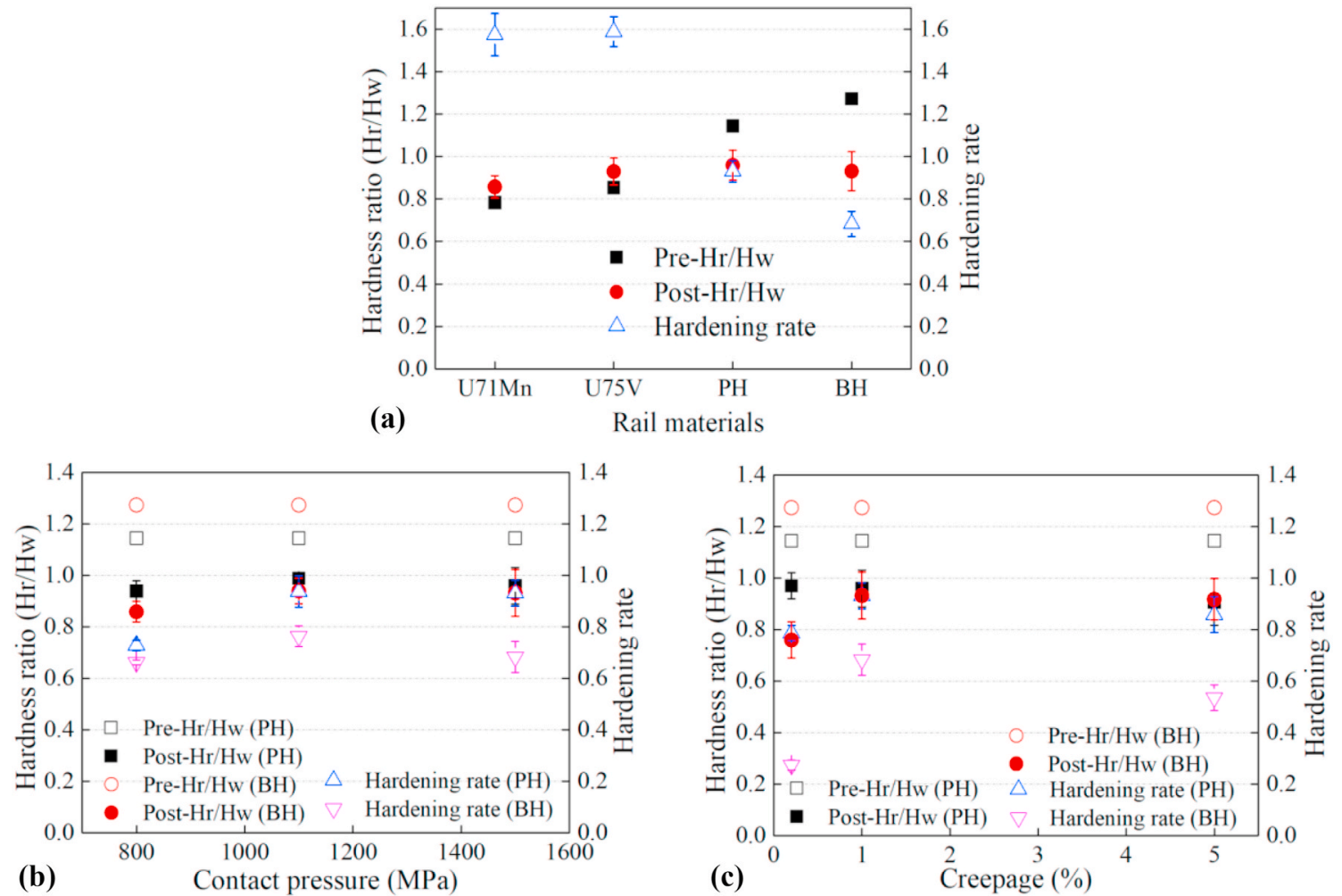

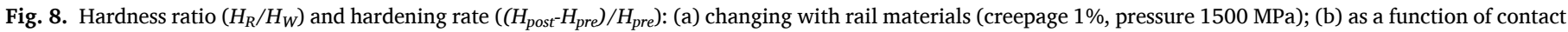
pressure (creepage 1\%); (c) as a function of creepage (pressure $1500 \mathrm{MPa}$ ). 

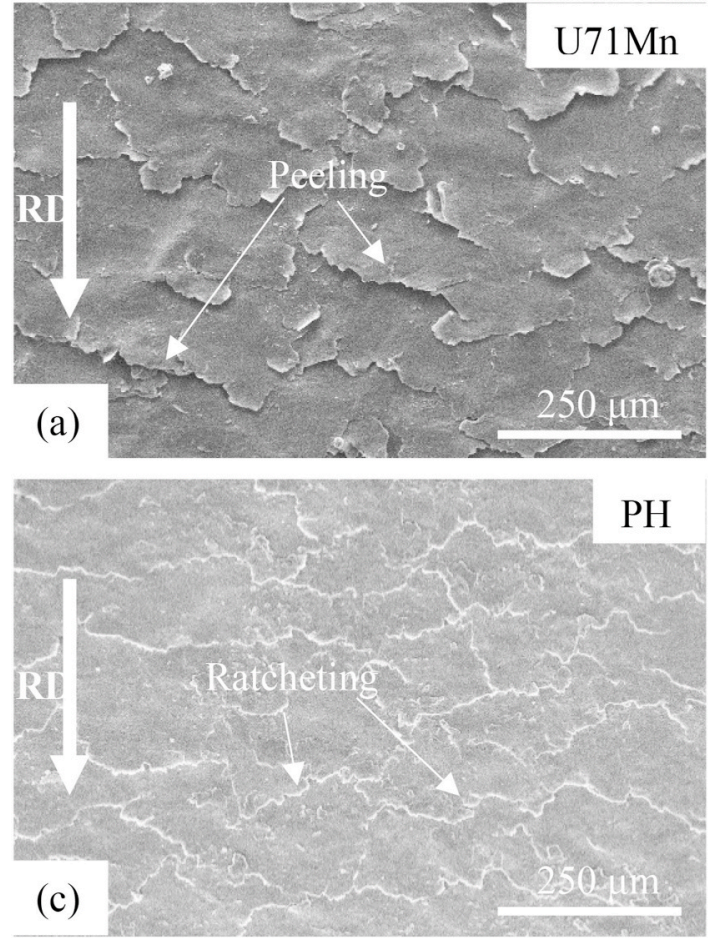
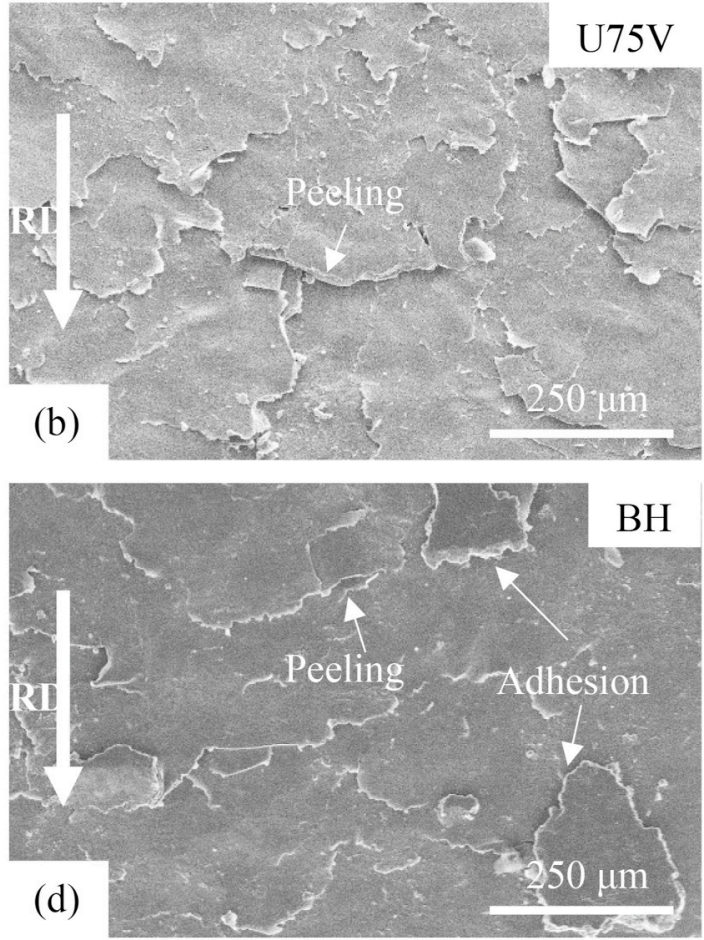

Fig. 9. Surface damage for different rail materials (creepage 1\%, pressure $1500 \mathrm{MPa}$ ): (a) U71Mn; (b) U75V; (c) PH; (d) BH.

U71Mn, U75V and BH rail steels are similar and severe, although the BH steel features the largest bulk hardness. Notably, the wear loss of the Cclass wheel appears to be related to its coupled rail material and, accordingly, the wheel running against the $\mathrm{PH}$ steel shows the largest wear rate (Fig. 4b). It potentially supports the results in the literature [42-44] that increasing the hardness of pearlitic rails would increase the wheel wear loss. Besides, the four sets of experiments present a similar total wear loss, which is in the range of $80 \mu \mathrm{g} / \mathrm{m} \sim 100 \mu \mathrm{g} / \mathrm{m}$ (Fig. $4 \mathrm{c}$ ).

Fig. 5 shows the wear rate variation with contact pressures for experiments related to the C-class-PH pair and the C-class-BH pair. Under the same creepage condition (1\%), the wear rates of both $\mathrm{PH}$ and $\mathrm{BH}$ rail steels, the associated wheel wear rates and the total wear rates increase with the rising contact pressure. Compared with $\mathrm{PH}$ rail steel, the $\mathrm{BH}$ rail steel displays a poor wear resistance (Fig. 5a), but relatively low wheel wear rates are shown for C-class-BH pairs under any contact pressure condition (Fig. 5b). A similar result was drawn in the literature [35] that the carbon-free bainitic rail was friendly to the matched wheel. Besides, there is no significant difference in the total wear rate between
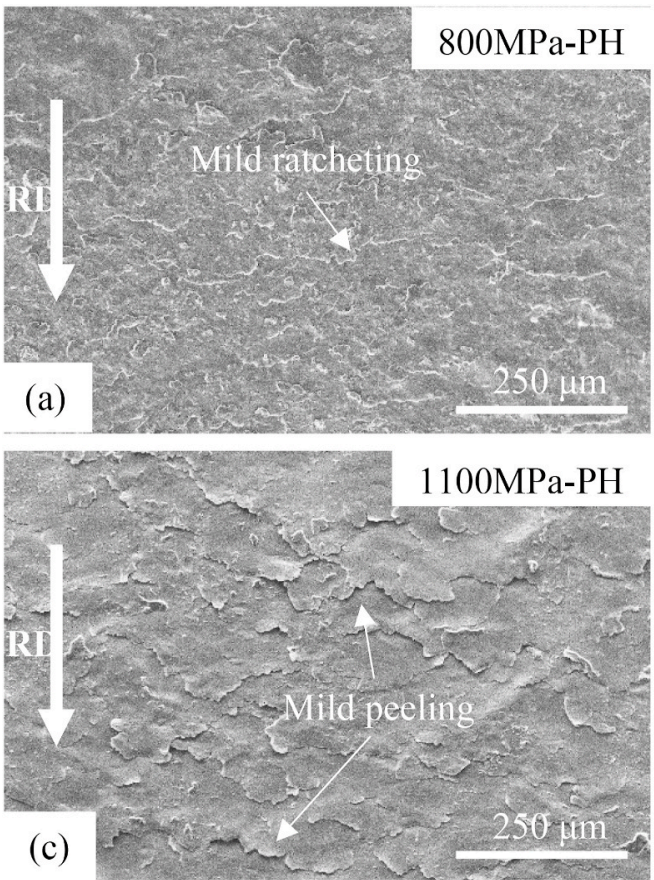
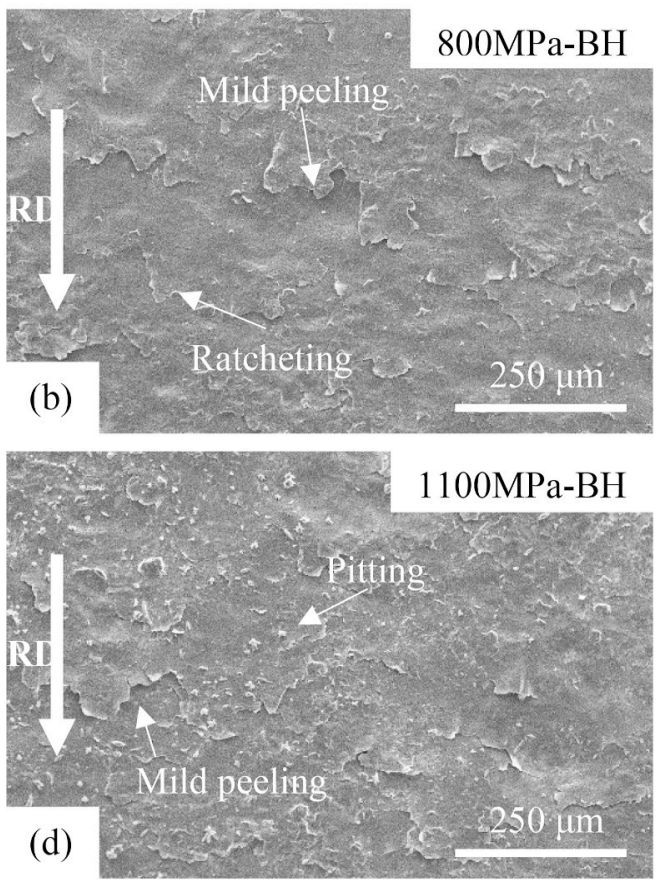

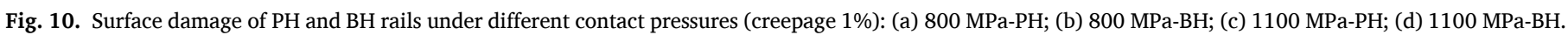



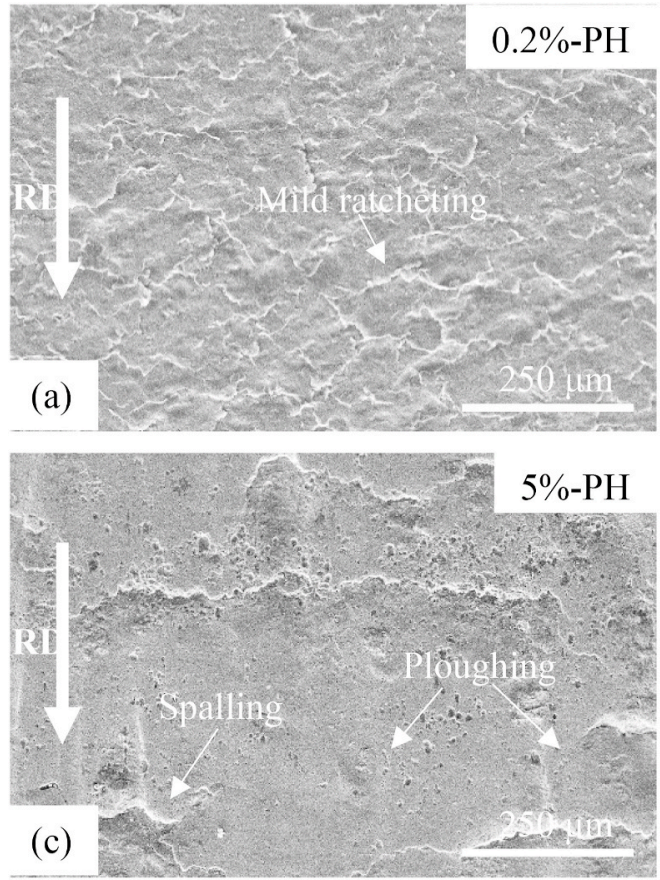
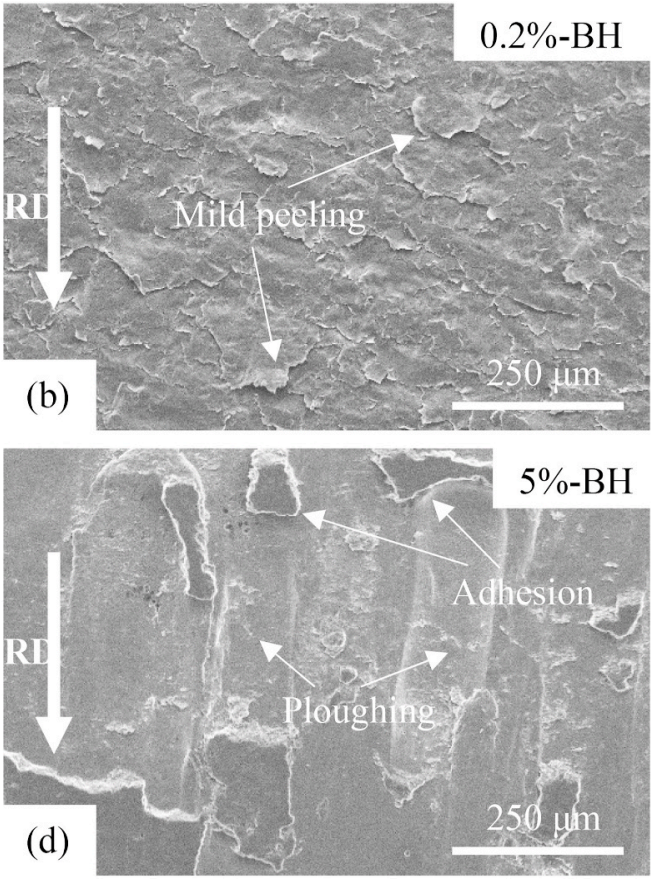

Fig. 11. Surface damage of $\mathrm{PH}$ and $\mathrm{BH}$ rails under different creepages (pressure $1500 \mathrm{MPa}$ ): (a) $0.2 \%-\mathrm{PH}$; (b) $0.2 \%-\mathrm{BH}$; (c) 5\%-PH; (d) 5\%-BH.

the two sets of pairs (Fig. 5c).

Fig. 6 shows the wear rate variation with creepages for C-class-PH pair and C-class-BH pair under the same stress condition (1500 MPa). As the creepage increases, the wear rates of $\mathrm{PH}$ and $\mathrm{BH}$ rail steels and of the C-class wheel matched with $\mathrm{BH}$ rail steel increase; however, the wear rate of the wheels matched with $\mathrm{PH}$ rail decreases when the creepage increases from $1 \%$ up to $5 \%$ (Fig. 6 b). The $\mathrm{PH}$ rail steel seems to have a better wear resistance than that of the $\mathrm{BH}$ rail steel at any creepage (Fig. 6a). Specially, at a large creepage of 5\%, the rail wear rate, wheel wear rate and total wear rate for C-class-PH pair are lower than that for $\mathrm{C}$-class-BH pair. It implies that the $\mathrm{PH}$ rail steel may possess excellent wear properties at severe sliding conditions.

The surface hardness evolution of rail discs before and after experiments is shown in Fig. 7. The rail discs have undergone significant work
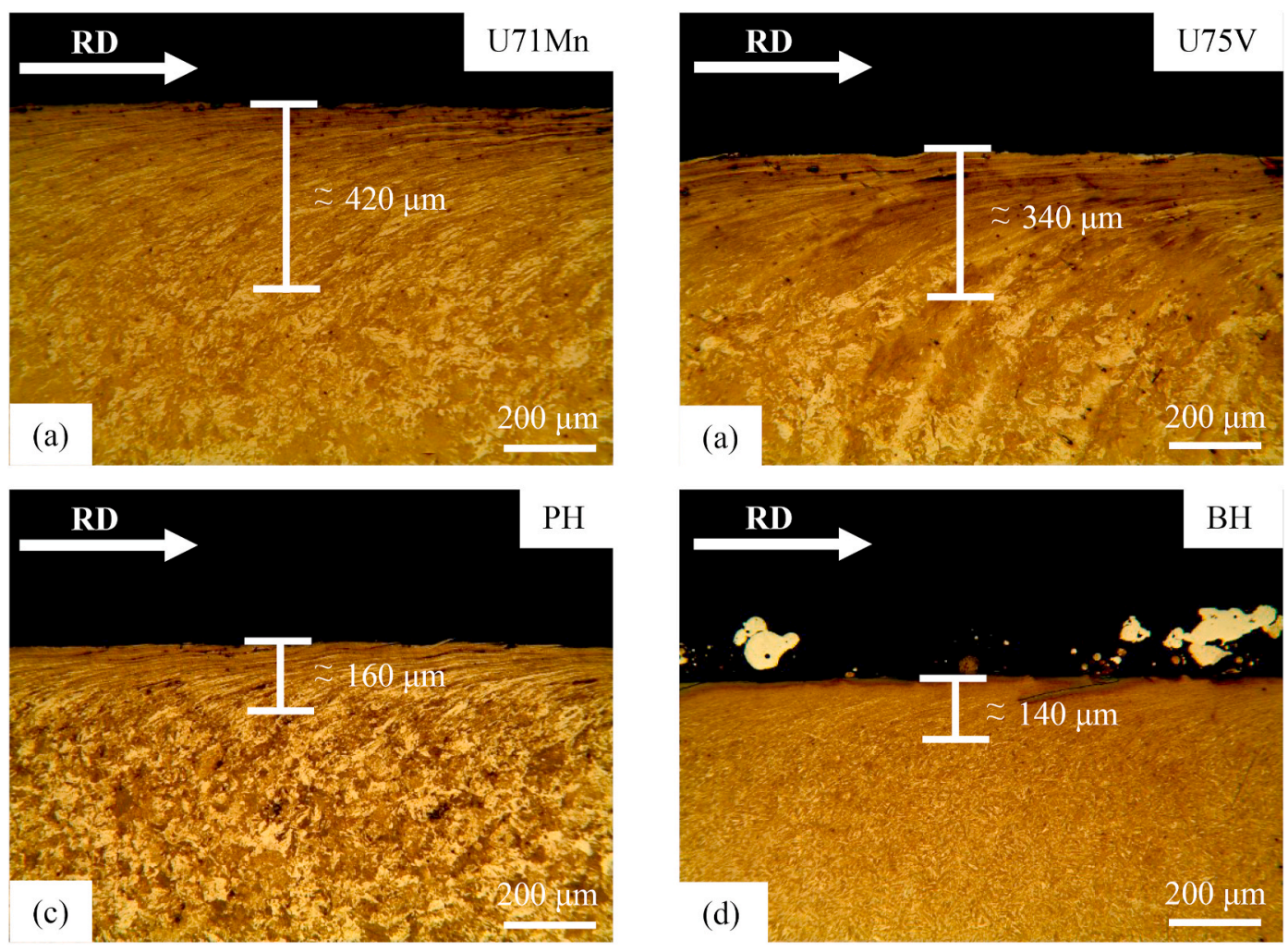

Fig. 12. Plastic deformation of different rail materials (creepage 1\%, pressure $1500 \mathrm{MPa}$ ): (a) U71Mn; (b) U75V; (c) PH; (d) BH. 

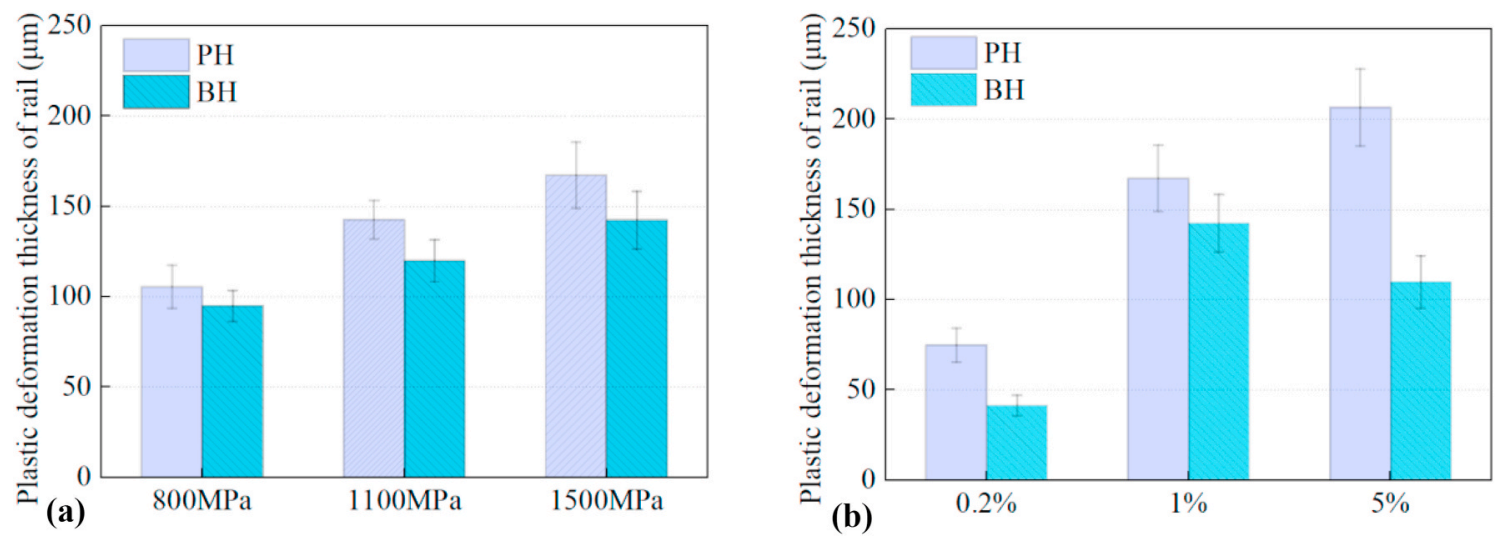

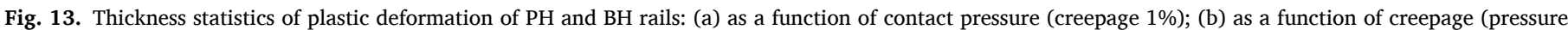
$1500 \mathrm{MPa})$.

hardening during rolling-sliding. The post-test rail surface hardness values of the rail materials across all experiments increase up to 700 $\mathrm{HV}_{0.5}-800 \mathrm{HV}_{0.5}$. Fig. 7 a shows similar post-test surface hardness values for the four types of rail steels, although their pre-test hardness' are significantly different. The post-test surface hardness' of $\mathrm{PH}$ and $\mathrm{BH}$ rail steels under different pressures also show similar values (Fig. 7b). On the contrary, a visible effect of creepage on the work hardening of BH steel can be observed in Fig. 7c: the post-test surface hardness of BH steel at a small creepage of $0.2 \%$ is much lower than that at larger creepages.

Fig. 8 presents the trend of rail/wheel hardness ratio $\left(H_{R} / H_{W}\right)$ and rail hardening rate (Hardening rate $=\left(H_{\text {post }} H_{\text {pre }}\right) / H_{\text {pre }}$, where $H_{\text {post }}$ and $H_{\text {pre }}$ are the pre-test and post-test surface hardness', respectively). The values of post-test $H_{R} / H_{W}$ across all experiments are close, in a range of $0.8-1.0$. The possible reason is that the post-test surface hardness' of the wheels and rails are similar across all experiments (Fig. 7), and the workhardening ability of the wheel material with pearlite-ferrite phase is generally higher than that of the rail material with a full pearlite phase. Specially, the post-test $H_{R} / H_{W}$ values for the C-class-PH pair and the Cclass-BH pair are markedly smaller than their pre-test $H_{R} / H_{W}$ values (Fig. 8a). Fig. 8b and c shows that as the contact pressure and creepage increase, the post-test $H_{R} / H_{W}$ values for the C-class-PH pairs and the Cclass-BH pairs still stabilize at 0.8-1.0. This means a greater drop from pre-test $H_{R} / H_{W}$ to post-test $H_{R} / H_{W}$ values for the C-class-BH pairs.

Fig. 8a shows that the hardening rate of the premium $\mathrm{PH}$ rail with high bulk hardness is significantly smaller than that of the standard U71Mn and U75V steels, whose hardening rate is about 1.6. Meanwhile, the $\mathrm{BH}$ steel with the highest bulk hardness presents the lowest hardening rate (about 0.75 ) due to its typical carbide-free bainitic microstructure. The hardening rates of $\mathrm{PH}$ and $\mathrm{BH}$ steels increase slightly as the contact pressure increases from $800 \mathrm{MPa}$ to $1100 \mathrm{MPa}$, and then remain stable as it increases up to $1500 \mathrm{MPa}$ (Fig. 8b). The hardening rates of $\mathrm{PH}$ and $\mathrm{BH}$ steels increase rapidly as the creepage increases from $0.2 \%$ to $1 \%$, and reduce slightly as it further increases to $5 \%$ (Fig. $8 \mathrm{c}$ ). Besides, under different rolling-sliding conditions, the hardening rates of $\mathrm{PH}$ steel are greater than that of BH steel (Fig. 8b and c).

\subsection{Surface damage}

The surface damage of the rail discs is shown in Figs. 9-11. Under the same contact condition (creepage 1\%, pressure $1500 \mathrm{MPa}$ ), the surface damage of U71Mn and U75V rail steels is severe, mainly by peeling (Fig. 9a and b), whereas that of PH steels is slight and dominated by ratcheting (the earlier stage of peeling), as shown in Fig. 9c. Notably, the hardest BH steel with bainitic structure is severely damaged and adhesion can be observed in Fig. 9d besides peeling damage. As the contact pressure increases, the surface damage of both $\mathrm{PH}$ and $\mathrm{BH}$ steels increases gradually (Fig. 10). Specifically, the surface damage of PH steel changes from ratcheting at $800 \mathrm{MPa}$ (Fig. 10a) to peeling at $1500 \mathrm{MPa}$ (Fig. 9c), whereas the one of $\mathrm{BH}$ steel shifts from mild peeling and ratcheting (Fig. 10b) to peeling and adhesion (Fig. 9d). With the increase in creepage, the surface damage of both $\mathrm{PH}$ and $\mathrm{BH}$ steels deteriorates significantly (Fig. 11). More in detail, the surface damage of PH steel transforms from ratcheting at $0.2 \%$ (Fig. 11a) to peeling and ploughing at 5\% (Fig. 11c), whereas the one of $\mathrm{BH}$ steel changes from slight peeling (Fig. 11b) to adhesion and ploughing (Fig. 11d). Notably, also in this case, the surface damage of $\mathrm{BH}$ steel is more severe than that of PH steel under the same rolling-sliding conditions (Figs. 10 and 11).

\subsection{Sub-surface plastic deformation}

The sub-surface of rail discs shows varying extents of plastic deformation during cyclic loading, as illustrated by Fig. 12. The deformation extent of pearlitic rail steels seems to be closely related to their bulk hardness. For example, at 1\% creepage and $1500 \mathrm{MPa}$ contact pressure, the deformation thickness of the $\mathrm{PH}$ steel (Fig. 12c) with high bulk hardness is visibly lower than that of the standard U71Mn and U75V steels (Fig. 12a and b). Furthermore, the plastic deformation of BH steel (Fig. 12d) with typical bainitic structure is relatively thin as well (about $140 \mu \mathrm{m}$ ). It is well known that plastic deformation is one of the major driving forces to promote the work hardening of pearlitic steels. The lower deformation extent may be the main reason to explain why $\mathrm{PH}$ and BH steels were less work hardened than other materials in Fig. 8a.

Fig. 13 presents the thickness statistics of plastic deformation for $\mathrm{PH}$ and $\mathrm{BH}$ rails under various creepages and pressures. As the contact pressure increases, the deformation of both $\mathrm{PH}$ and $\mathrm{BH}$ steels tends to rise slightly (Fig. 13a). Fig. 13b highlights a marked effect of the creepage on the deformation of $\mathrm{PH}$ and $\mathrm{BH}$ materials. At a small creepage of $0.2 \%$, there is almost no visible deformation of both the materials. As the creepage increases up to $5 \%$, the deformation thickness of the PH steel increases up to about $200 \mu \mathrm{m}$. Furthermore, the bainitic $\mathrm{BH}$ steel exhibits thinner deformation and less obvious plastic flow than $\mathrm{PH}$ steel under all working conditions.

In order to compare the microstructure evolution of the four rail materials, SEM observations were performed at different depths from the surface, as shown in Fig. 14. Naturally, the topmost layer of the three types of pearlitic rail steels (Fig. 14a,c,e) has been severely degraded, without lamellar pearlite features. A fibrous structure parallel to the surface is visible on the topmost layer of U71Mn, U75V and PH discs. Moreover, at a certain depth from the surface, the kinks and fragmentations of cementite, as well as the rearrangement of the fine ferrites toward the shear stress direction are visible (Fig. 14b,d,f).

The microstructure evolution of bainitic steels is different from that of pearlitic steels during plastic deformation. As reported from a previous study [46], during the deformation of carbide-free bainitic steel, the 

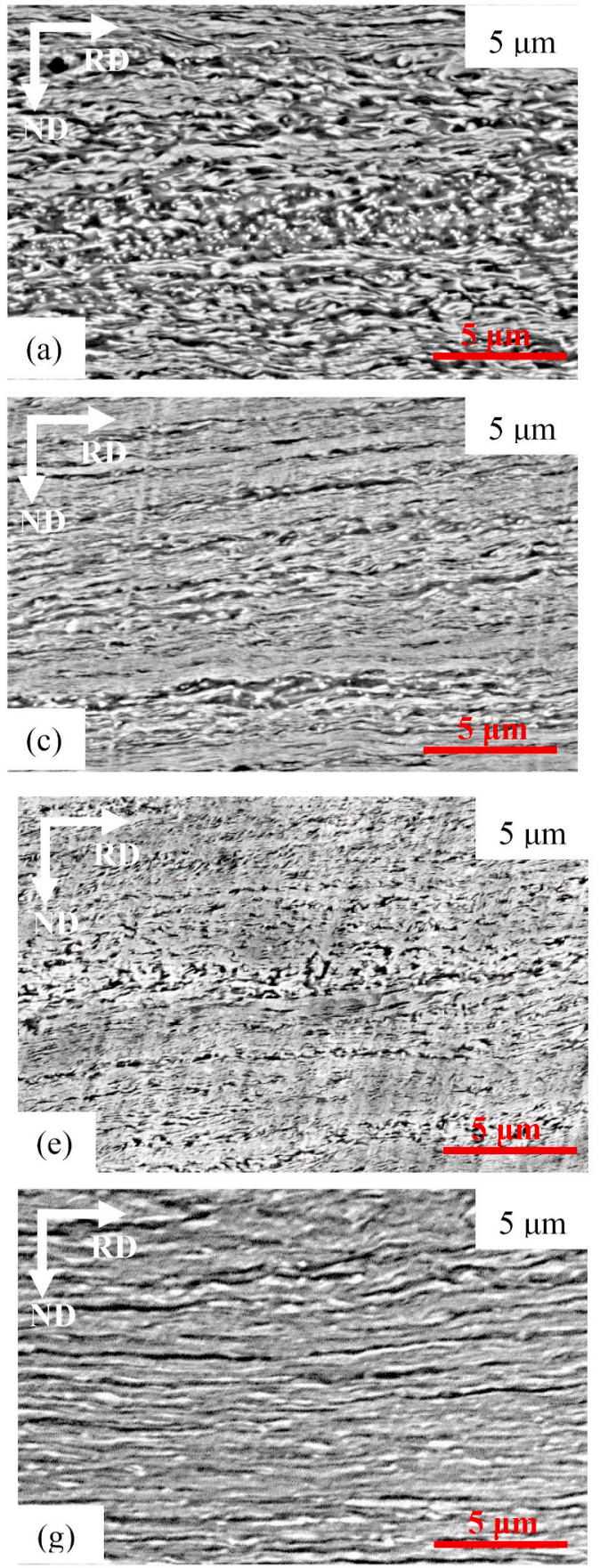
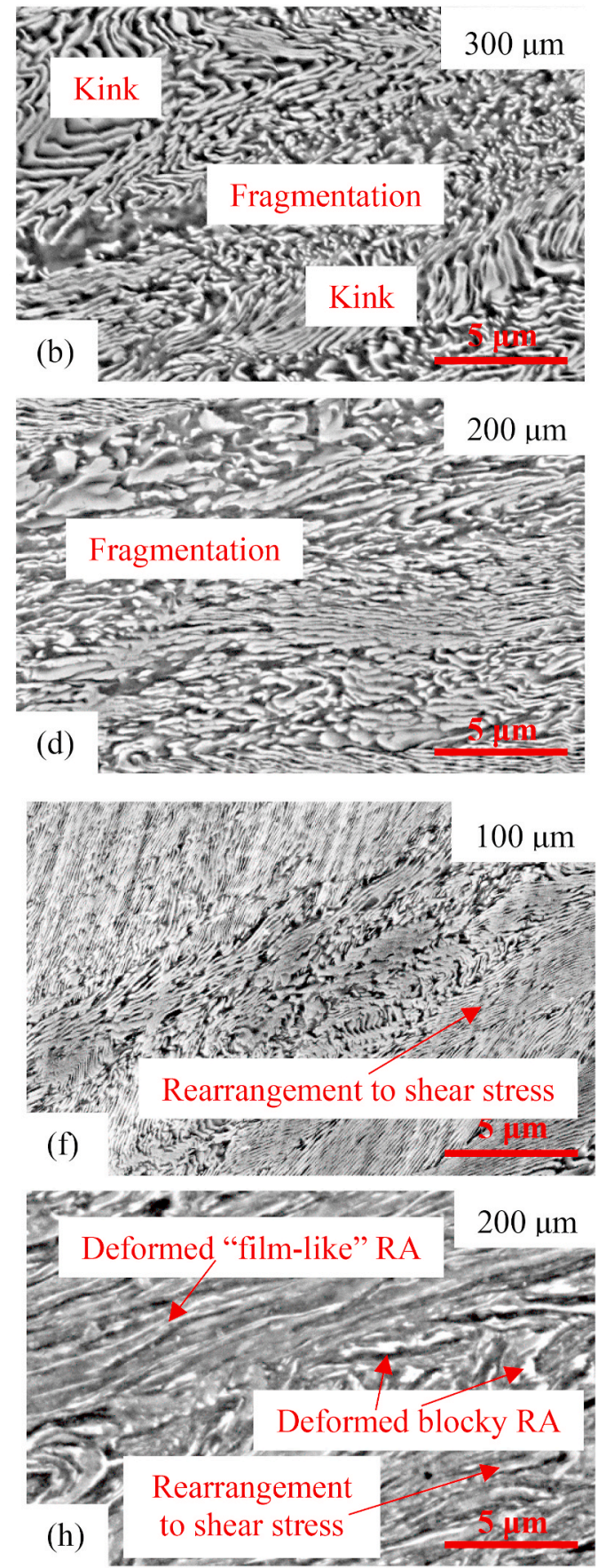

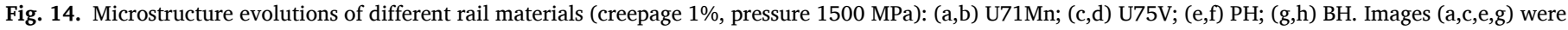
taken from topmost surface and $(b, d, f, h)$ were taken from different depth sections according to the deformation depth.

metastable RA deformed first and, subsequently, transformed into strain-induced martensite. At that point, all the microstructural constituents (BF, martensite, RA) deformed simultaneously. In this work, Fig. 14h shows that the deformed "film-like" RA, the blocky RA and the rearrangement of $\mathrm{BF}$ in shear stress direction appear on $\mathrm{BH}$ rail steel at $100 \mu \mathrm{m}$ below surface. Besides, in the topmost layer of BH material (Fig. 14g), the marked refinement of martensite and BF, as well as the formation of fibrous structure, is visible.

The similar fibrous structure on the topmost layer of the four rail materials may be the main reason for the similar post-test surface hardness (Fig. 7a). The discontinuous "film-like" RA and the transformation induced plasticity (TRIP) effect make the compatible deformation capacity of BF-RA-martensite crystal structure in bainitic steel better than that of cementite and ferrite in pearlitic steel, resulting in a relatively thin deformation on BH rail steel (Figs. 12 and 13).

Plastic flow and residual stresses generated and accumulated on the rail surface layer during the deformation. The plastic flow raised the elastic limit, whereas residual stresses suppressed plastic flow. The combined effect was marked as "work hardening" [47]. The hardness variation of the four rail steels, as a function of the distance from the contact surface, was measured at intervals of $50 \mu \mathrm{m}$ as shown in Fig. 15. A decrease in hardness with increasing depth from the surface can be observed. At the same depth, the hardness of $\mathrm{BH}$ rail steel is higher than that of U71Mn, U75V and PH, whereas, due to the high bulk hardness of $\mathrm{BH}$ steel, it's work hardening extent is lower than the pearlitic rails. The work hardening of pearlitic materials is related to dislocation density 


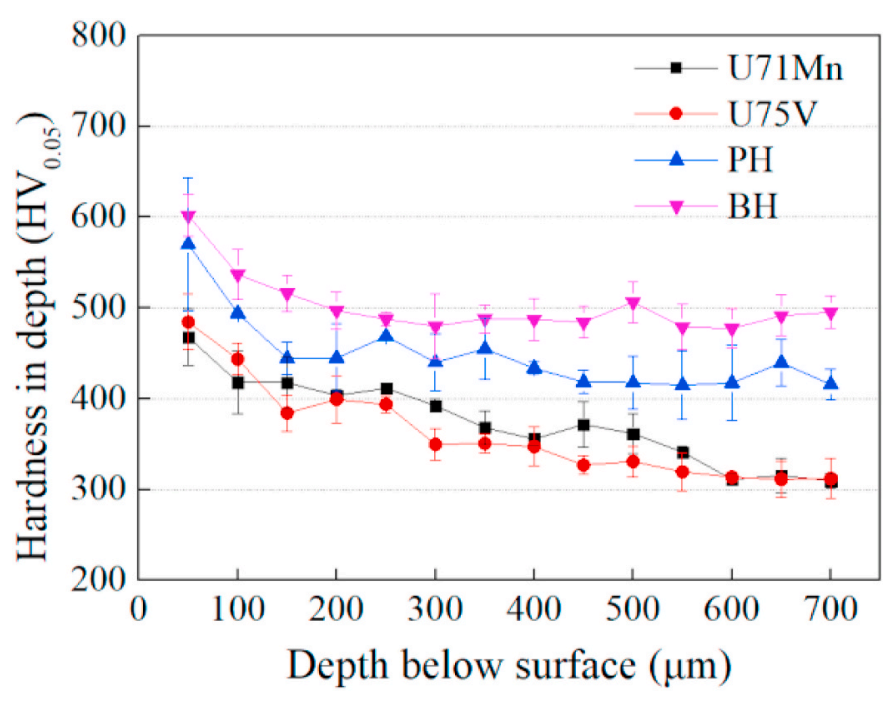

Fig. 15. Hardness variations for different rail materials in depth (creepage $1 \%$, pressure $1500 \mathrm{MPa}$ ).

and ferrite grain refinement during the deformation [48], whereas the work hardening of bainitic materials is connected to the density of mobile dislocations in BF, the strain-induced transformation of RA to martensite and the refined size of $\mathrm{BF}$ grains [46]. Therefore, it is necessary to perform further observations such as electron backscattered diffraction (EBSD) and transmission electron microscopy (TEM) to explain the lower hardening rate and the higher wear rate on the $\mathrm{BH}$ rail steel.

\subsection{Fatigue cracks}

Fig. 16 and Table 4 present the SEM observations and the size statistics of fatigue cracks for the four types of rail materials. One wheel disc and one rail disc were randomly selected for each set of experiment. Three small pieces of about $1 \mathrm{~mm}$ length were taken from each disc and each piece was separated by $120^{\circ}$ from the others, as shown in Fig. 2 b. All cracks in the three small pieces were measured and counted. Numerous surface cracks and sub-surface cracks were found on the four kinds of rail steels. Under 1\% creepage and $1500 \mathrm{MPa}$ contact pressure, the cracks initiated near the surface and then grew intergranularly into the rail at a shallow angle $\left(8.6^{\circ} \sim 10.8^{\circ}\right)$. For pearlitic rail materials (U71Mn, U75V and PH), the crystal orientation and grain boundary distribution of the refined pearlite colonies have significant effects on fatigue crack initiation and propagation [49]. Crack tip blunting, that occurred at numerous broken cementite and kink structures, is visible in Fig. 16a-c. Besides, Fig. 16c exhibits branching and a change in crack propagation direction at the kink structures. This is because the dense ferrite/cementite interfaces in these structures can absorb crack propagation energy and effectively reduce the stress intensity factor at the crack tip, hindering the plastic flow and crack propagation. For the bainitic $\mathrm{BH}$ rail steel, the cracks are blunted by the presence of deformed "film-like" RA, as shown in Fig. 16d. The stress intensity factor at the crack tip was reduced by the TRIP effect, the blocks micro-crack propagation (BMP) effect and the change of residual stresses, hindering the further growth of cracks in bainitic steel [50].

The appearance of both short and long cracks in the cross section of
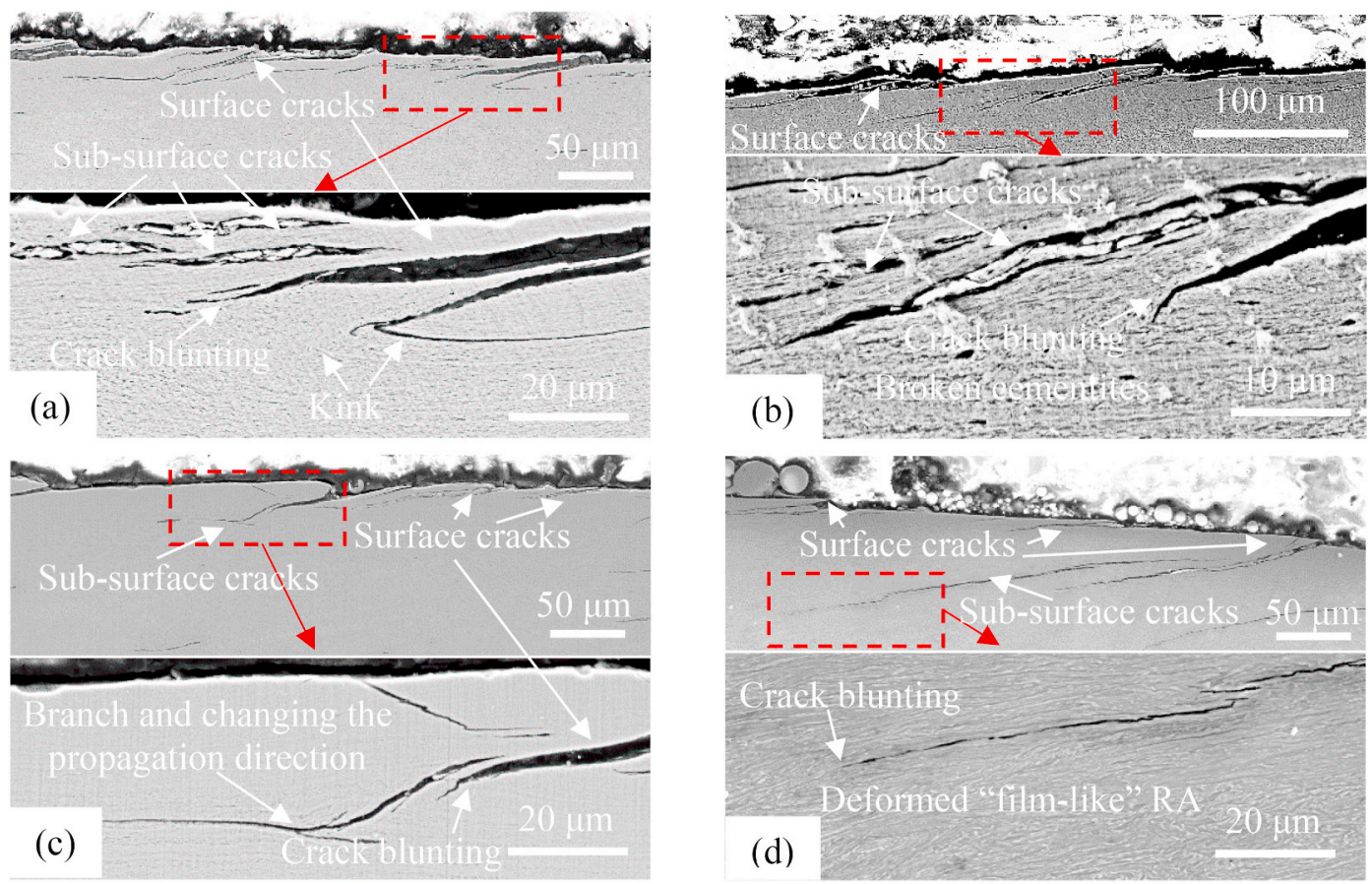

Fig. 16. Fatigue cracks for different rail materials (creepage 1\%, pressure 1500 MPa): (a) U71Mn; (b) U75V; (c) PH; (d) BH.

Table 4

The size statistics of fatigue cracks for various rail materials (creepage 1\%, pressure $1500 \mathrm{MPa}$ ).

\begin{tabular}{lllllll}
\hline Rail grades & Average depth $(\mu \mathrm{m})$ & Maximum depth $(\mu \mathrm{m})$ & Average length $(\mu \mathrm{m})$ & Maximum length $(\mu \mathrm{m})$ & Average angle $($ Deg.) & Maximum angle $($ Deg.) \\
\hline U71Mn & $14.1 \pm 7.3$ & 33.2 & $99.5 \pm 63.2$ & 271.9 & $9.2 \pm 3.4$ & 15.8 \\
U75V & $21.0 \pm 18.3$ & 90.2 & $148.5 \pm 89.9$ & 436.8 & $8.6 \pm 3.7$ & 14.5 \\
PH & $15.5 \pm 7.1$ & 34.0 & $99.4 \pm 67.4$ & 306.4 & $10.8 \pm 4.9$ & 27.4 \\
BH & $18.6 \pm 11.1$ & 44.1 & $147 \pm 102.9$ & 393.3 & $8.7 \pm 3.8$ & 20.5 \\
\hline
\end{tabular}



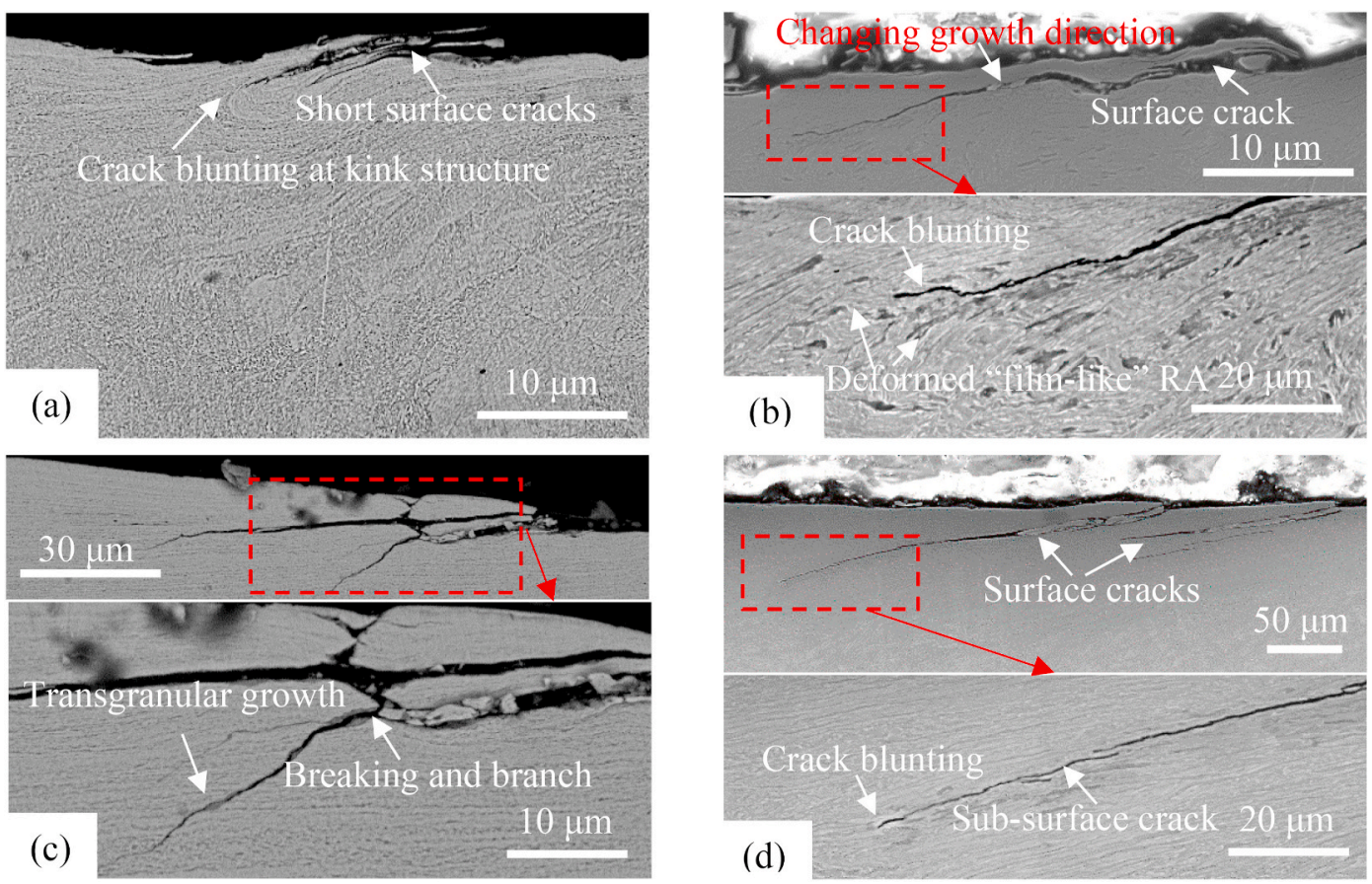

Fig. 17. Fatigue cracks of $\mathrm{PH}$ and $\mathrm{BH}$ rails under different creepages (pressure $1500 \mathrm{MPa}$ ): (a) $0.2 \%-\mathrm{PH}$; (b) $0.2 \%-\mathrm{BH}$; (c) 5\%-PH; (d) 5\%-BH.

Table 5

The size statistics of fatigue cracks on $\mathrm{PH}$ and $\mathrm{BH}$ rail discs under various conditions.

\begin{tabular}{|c|c|c|c|c|c|c|}
\hline \multirow[t]{2}{*}{ Creepage/Pressure } & \multicolumn{3}{|l|}{$\mathrm{PH}$} & \multicolumn{3}{|l|}{$\mathrm{BH}$} \\
\hline & Average depth $(\mu \mathrm{m})$ & Average length $(\mu \mathrm{m})$ & Average angle (Deg.) & Average depth $(\mu \mathrm{m})$ & Average length $(\mu \mathrm{m})$ & Average angle (Deg.) \\
\hline $0.2 \% / 1500 \mathrm{MPa}$ & $3.7 \pm 2.0$ & $24.0 \pm 10.7$ & $9.6 \pm 4.2$ & $8.3 \pm 4.2$ & $69.1 \pm 31.2$ & $7.2 \pm 2.3$ \\
\hline 1\%/1500 MPa & $15.5 \pm 7.1$ & $99.4 \pm 67.4$ & $10.8 \pm 4.9$ & $18.6 \pm 11.1$ & $147.1 \pm 102.8$ & $8.7 \pm 3.8$ \\
\hline 1\%/800 MPa & $7.3 \pm 5.0$ & $58.3 \pm 46.9$ & $8.6 \pm 3.9$ & $14.8 \pm 6.6$ & $92.5 \pm 49.7$ & $9.8 \pm 3.1$ \\
\hline 1\%/1100 MPa & $16.8 \pm 6.1$ & $141.0 \pm 64.4$ & $7.7 \pm 2.8$ & $18.3 \pm 7.8$ & $122.3 \pm 53.4$ & $8.9 \pm 2.5$ \\
\hline 1\%/1500 MPa & $15.5 \pm 7.1$ & $99.4 \pm 67.4$ & $10.8 \pm 4.9$ & $18.6 \pm 11.1$ & $147.1 \pm 102.8$ & $8.7 \pm 3.8$ \\
\hline
\end{tabular}

rail discs results in a certain variance of the statistical crack size, as listed in Table 4. In general, the average values of crack depth and length for PH and U71Mn steels are small (about $15 \mu \mathrm{m}$ deep and $100 \mu \mathrm{m}$ long), suggesting that these two materials possess excellent RCF resistance. On the contrary, the U75V and BH steels present poor RCF resistance according to the larger average crack depth and length.

The fatigue cracks of $\mathrm{PH}$ and $\mathrm{BH}$ rail steels are counted and analyzed as a function of creepage and contact pressure, as shown in Fig. 17 and Table 5. Generally, the fatigue crack sizes (especially crack length) in these two rail materials show an upward trend with increasing creepage and contact pressure. Specifically, at a small creepage of $0.2 \%$, the $\mathrm{PH}$ steel is typified by short surface cracks (Fig. 17a), with an average depth of $3.7 \mu \mathrm{m}$, an average length of $24 \mu \mathrm{m}$ and an average angle of $9.6^{\circ}$, whereas the BH steel presents a longer surface crack, with an average length of $69.1 \mu \mathrm{m}$ (Fig. 17b). A change in surface crack propagation direction along the deformed RA can be seen in Fig. 17b. At a large creepage of $5 \%$, the crack depth and angle of $\mathrm{PH}$ steels significantly increase due to the large shear stress up to $25.3 \mu \mathrm{m}$ and $16.3^{\circ}$, respectively (Fig. 17c). Besides, the cracks in PH steel grows into the matrix transgranularly. The fragmentation and branch of cracks is visible in Fig. 17c, while such phenomenon is very weak in BH steel (Fig. 17d).

In general, the crack length in $\mathrm{BH}$ discs is greater than that in $\mathrm{PH}$ discs under the same conditions. However, because of the better compatible deformation capacity of bainitic structure, the $\mathrm{BH}$ rail steel exhibits a thinner deformation thickness (Fig. 13) and a smaller change of crack depth and angle with contact conditions (Table 5).

\section{Discussion}

\subsection{Wear regime transition}

In order to directly compare and analyze the relationship between wear loss and contact conditions, an energy approach has been extensively adopted [7,12,39,41], which involves plotting wear rate in $\mu \mathrm{g} / \mathrm{m} / \mathrm{mm}^{2}$ against $T \gamma / A$, where $T$ is the tangential force at the contact interface in $\mathrm{N}, \gamma$ the creepage and $A$ the contact area in $\mathrm{mm}^{2}$. Fig. 18 presents the wear results of this work and previous studies [7,12,39-41, 49,51-55] as a function of $T \gamma / A$. According to the sudden change of the wear rate with $T \gamma / A$, three wear regimes could be identified for rail and wheel materials in this work (Fig. 18a,c,e): Type I (mild), Type II (severe) and Type III (catastrophic). As the $T \gamma / A$ increases from 0 to 120 $\mathrm{N} / \mathrm{mm}^{2}$, wear rates of rail and wheel are seen to increase steadily in Type I, then level off in Type II and finally increase rapidly in Type III.

Obviously, the wear rates of this work are mainly distributed in Type I and Type II. The wear rates of PH and BH rail steels (Fig. 18b) are similar with that of other rail materials (standard carbon rail [55], BS11, UICA, UICB, 1\% chrome rails [54], UIC60 900A rail [53], U75V rail [12, $39,49]$ and U71Mn $[39,40,51])$ for the $T \gamma / A$ values less than $20 \mathrm{~N} / \mathrm{mm}^{2}$ (i.e. Type I), whereas they are significantly lower than that of standard rail steels with lower hardness' for the higher $T \gamma / A$ values (about 30 $\mathrm{N} / \mathrm{mm}^{2}$ ). However, the advanced $\mathrm{R} 400 \mathrm{HT}$ rail (435HV) presents slightly lower wear rates than that of $\mathrm{PH}$ and $\mathrm{BH}$ rail steels for nearly all $T \gamma / \mathrm{A}$ values (Fig. 18a and b). Besides, the matched C-class wheel material 

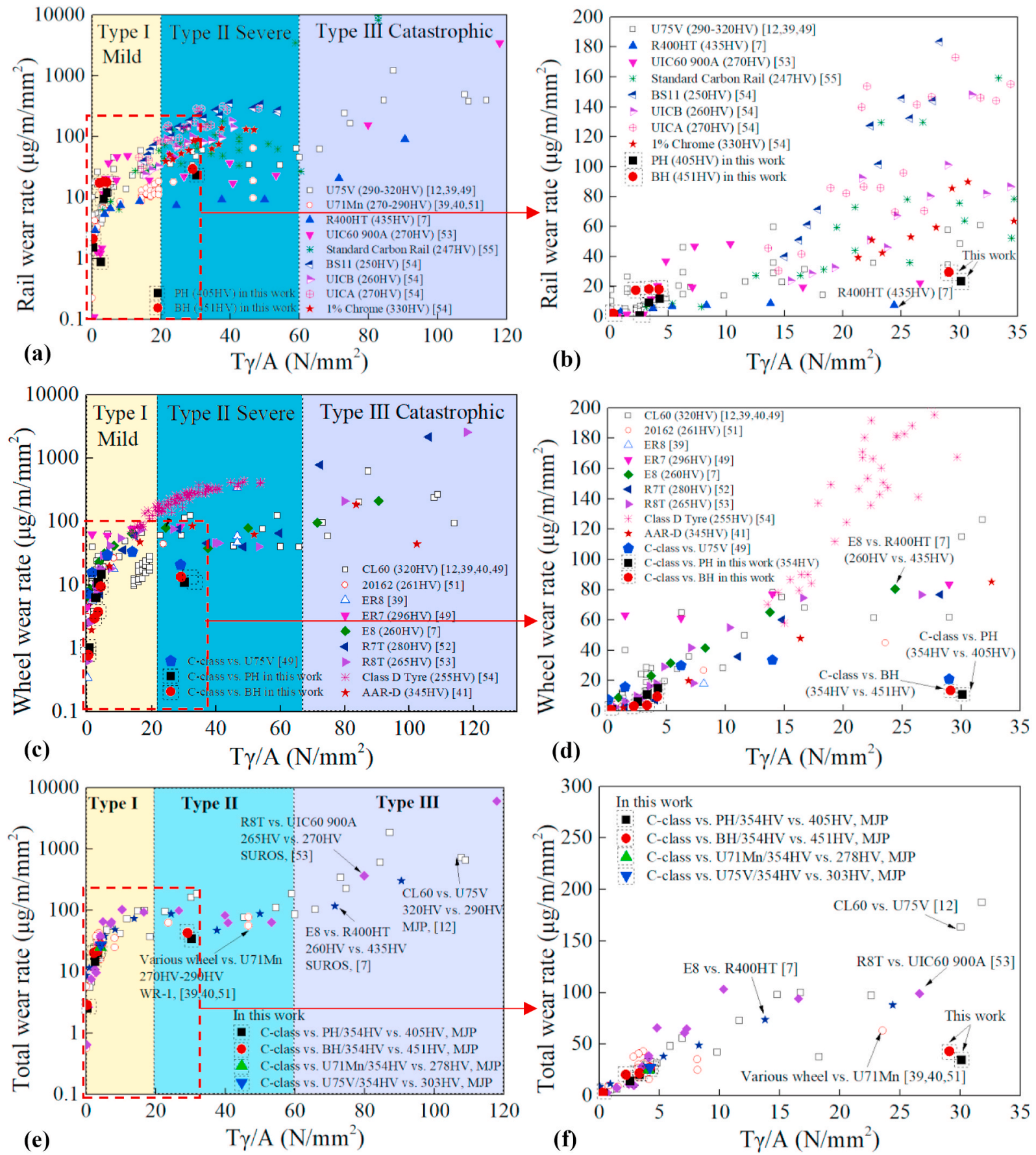

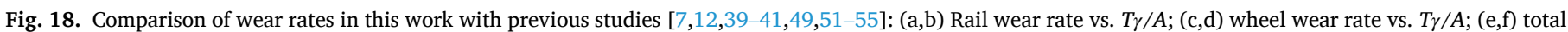
wear rate vs. $T \gamma / A$.

shows a remarkable wear resistance for all the $T \gamma / A$ values (Fig. 18c and d). Notably, the total wear rate in Fig. 18e presents only a weak correlation with test machines (SUROS, WR-1, MJP) and wheel-rail pairs, but is mainly related to $T \gamma / A$. Similarly, it can also be divided into the above three stages. Nevertheless, probably due to the excellent wear resistance of C-class wheel, the total wear rates of C-class-PH pair and C-class-BH pair are lower than that of E8-R400HT pair for the high $T \gamma / A$ values (about $30 \mathrm{~N} / \mathrm{mm}^{2}$ ).

In addition to contact conditions, hardness and work hardening also play vital roles in wear response for wheel and rail. It is well known that there is a distinct trend of decreasing wear rate with increasing hardness for pearlitic and bainitic steels. In this work, the wear rate of the harder $\mathrm{PH}$ rail steel $\left(405 \mathrm{HV}_{0.5}\right)$ is considerably lower than those of the soft
U71Mn (278 $\left.\mathrm{HV}_{0.5}\right)$, U75V (303 $\left.\mathrm{HV}_{0.5}\right)$ rail steels and other standard rail steels (standard carbon rail with $247 \mathrm{HV}$ [55], BS11 with $250 \mathrm{HV}$ [54], UICA with 270 HV [54], UICB with 260 HV [54], UIC60 900A with 270 $\mathrm{HV}$ [53]). Meanwhile, the wear rate of the high-hardness bainitic BH rail steel $\left(451 \mathrm{HV}_{0.5}\right)$ is similar to those of U71Mn and U75V steels and lower than those of other rail steels [53-55] possessing hardness' less than 300 HV. Besides, the hardening rate of bainitic steel is significantly lower than that of pearlitic steel (Fig. 8). This was considered to be the key reason for the high wear loss of bainitic steel [32,35,38]. However, the $\mathrm{PH}$ steel with low hardening rate shows a better wear resistance than U71Mn and U75V steels with high hardening rate (Fig. 8a). Therefore, the poor wear response of bainitic rails may also be attributed to its unique structural evolution. 

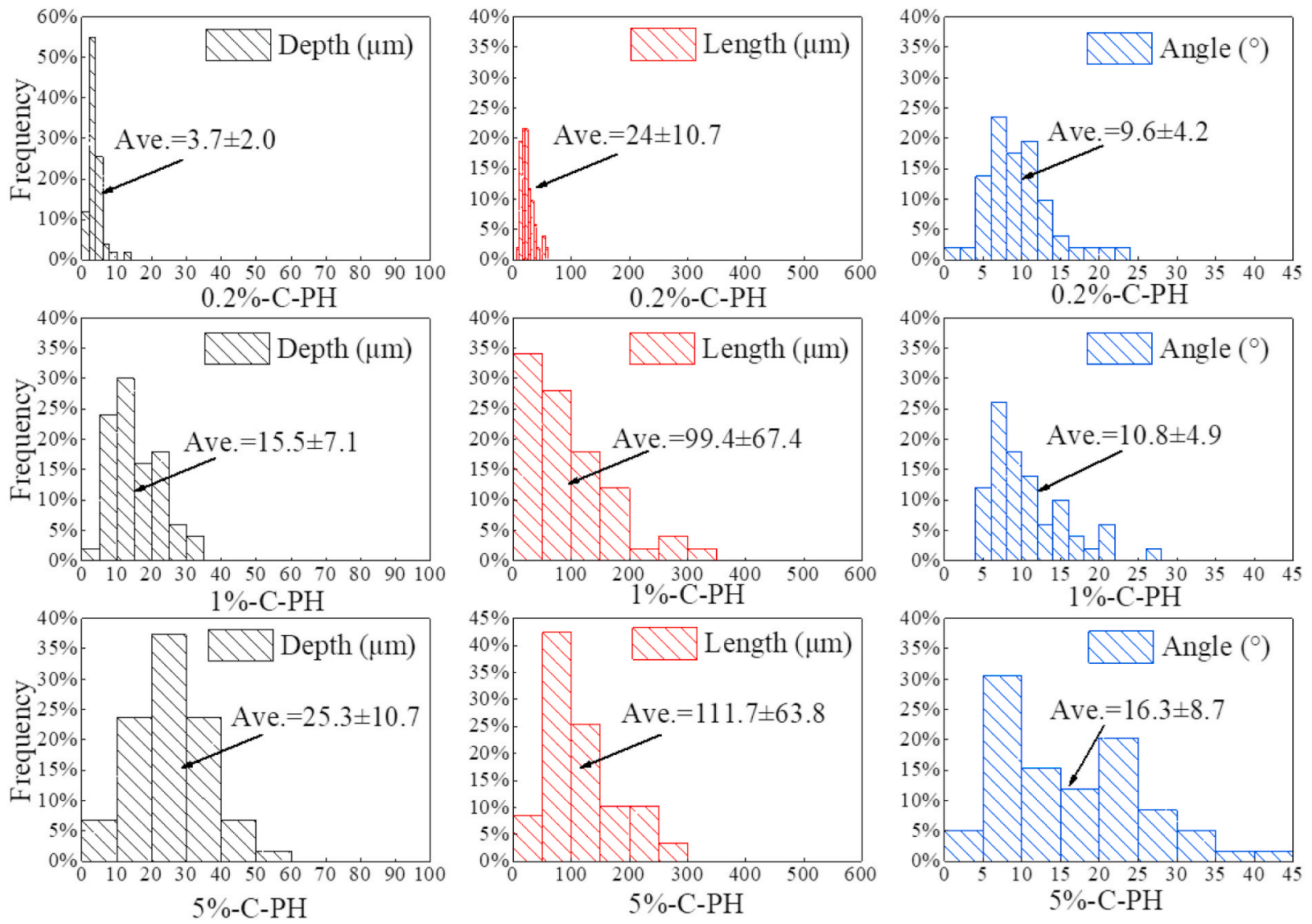

Fig. 19. Fatigue crack size histogram for $\mathrm{PH}$ rail under different creepages (pressure $1500 \mathrm{MPa}$ ).

Furthermore, the wear performance of wheel and rail materials is affected in some cases by the matched materials in addition to its own bulk hardness [48]. For example, increasing the hardness of wheel or rail may increase the wear on the matched rail or wheel while reducing its own wear. Comparing the E8-R400HT pair [7] with the C-class-PH pair and the C-class-BH pair, the reason for the low wear rate of the R400HT rail may not only be the superior performance of the R400HT rail, but also the fact that the matched E8 wheel $(260 \mathrm{HV})$ is softer than the C-class wheel $\left(354 \mathrm{HV}_{0.5}\right)$, which is also the main reason for the higher total wear rate of E8-R400HT pair (Fig. 18f). Consequently, to accurately compare the wear characteristics of different materials, it is necessary to maintain the consistency of the matched materials and contact conditions.

\subsection{RCF damage evolution of $P H$ and $B H$ rail materials}

The above analysis of sub-surface damage indicated that the RCF damage of $\mathrm{PH}$ rail steel significantly increased with the increasing contact condition (creepage and pressure, i.e., $T \gamma / A$ ). Specifically, as the $T \gamma / A$ increased from $0.321 \mathrm{~N} / \mathrm{mm}^{2}$ up to $30.084 \mathrm{~N} / \mathrm{mm}^{2}$, the surface damage of PH steel transformed from ratcheting (Fig. 11a) to peeling and ploughing (Fig. 11c), and the plastic deformation thickness increased from $80 \mu \mathrm{m}$ up to $200 \mu \mathrm{m}$ (Fig. 13a). Meanwhile, the formation of a fibrous structure induced by the refinement and rearrangement of pearlite grains resulted in the appearance of work hardening from the inside of the material toward the contact interface (Fig. 15).

Besides, the fatigue crack size of $\mathrm{PH}$ material also showed an increasing trend with $T \gamma / A$. The distribution of crack size as a function of the creepage is shown in Fig. 19 (pressure $1500 \mathrm{MPa}$ ). At $0.2 \%$ creepage $\left(T \gamma / A=0.321 \mathrm{~N} / \mathrm{mm}^{2}\right)$, the crack depth, length and growth angle are mainly distributed in the intervals $0-10 \mu \mathrm{m}, 0-50 \mu \mathrm{m}$ and $0-25^{\circ}$, respectively. Their average values are $3.7 \mu \mathrm{m}, 24.0 \mu \mathrm{m}$ and $9.6^{\circ}$, respectively. As the creepage reaches 5\% ( $T \gamma / A$ increases up to 30.084 $\mathrm{N} / \mathrm{mm}^{2}$ ), the crack depth is distributed in the range 0-60 $\mu \mathrm{m}$ with average value increased up to $25.3 \mu \mathrm{m}$, the crack length is located in the range $0-300 \mu \mathrm{m}$ with average value increased up to $111.7 \mu \mathrm{m}$, and, finally, the crack angle is scattered in the range $0-45^{\circ}$ with average value increased up to $16.3^{\circ}$. Furthermore, due to the high stress intensity factor at the crack tip for large $T \gamma / A$, the crack propagation mechanism changed from intergranular propagation (cracks grow along grain boundaries, shown in Fig. 17a) to a mixed mode of intergranular and transgranular propagation (cracks grow through grain boundaries, shown in Fig. 17c).

Similarly, the RCF damage of $\mathrm{BH}$ rail steel also presented an ascending trend with $T \gamma / A$. Notably, the surface damage of BH steel was more severe than that of $\mathrm{PH}$ steel under the same rolling-sliding conditions (Figs. 10 and 11). The relatively shallow plastic deformation thickness of BH steel (Fig. 13) may be the main reason for the low level of work hardening of the BH steel (Fig. 15). In general, the crack length in $\mathrm{BH}$ discs was greater than that in $\mathrm{PH}$ discs under the same conditions. However, because of the better compatible deformation capacity of the bainitic structure induced by TRIP effect, the cracks of BH rail mainly grew along grain boundaries and were not prone to transgranular propagation.

In summary, the premium PH steel showed good wear resistance and anti-RCF performance, while the BH steel was comparable to standard pearlitic steels (U71Mn and U75V). However, the reasons for the differences in wear response and hardening rate are still unclear. Therefore, further study on the microstructure evolution, hardening mechanism and their correlation with wear response of the four rail materials should be systematically carried out to help develop improved bainitic rail materials. 


\section{Conclusions}

In this work, the wear and RCF of a premium pearlitic rail (PH), a carbon-free bainitic rail (BH) and two Chinese standard pearlitic rails (U71Mn and U75V) were investigated and compared. The wear regime and RCF damage evolution of the $\mathrm{PH}$ and $\mathrm{BH}$ rail materials under different contact conditions (creepage and pressures, i.e. $T \gamma / A$ ) were analyzed. The following main conclusions can be drawn:

1. Under the same rolling-sliding condition (creepage 1\%, contact pressure $1500 \mathrm{MPa}$ ), the high-hardness carbon-free bainitic steel, $\mathrm{BH}$, was similar to the standard rail steels, U71Mn and U75V, in terms of wear resistance. Compared with the $\mathrm{BH}$ steel, the highperformance pearlitic steel, $\mathrm{PH}$, presented a better wear resistance for all the contact conditions. Whereas, using the $\mathrm{BH}$ steel would be better for the wheel wear.

2. The post-test rail/wheel hardness ratio $\left(H_{R} / H_{W}\right)$ was centralized in 0.8-1.0, and the post-test surface hardness of the four types of rail materials was similar. The hardening rates of high-hardness $\mathrm{PH}$ and BH steels were significantly lower than those of U71Mn and U75V steels, and the bainitic steel (BH) underwent minimal work hardening due to the low extent of deformation.

3. The surface damage of pearlitic rails (U71Mn, U75V and PH) was typified by ratcheting and peeling, while that of the bainitic rails (BH) was accompanied by another damage, adhesion. Besides, the surface damage of $\mathrm{BH}$ steel was more severe than that of $\mathrm{PH}$ steel under the same rolling-sliding conditions.
4. As $T \gamma / A$ increased from $0.321 \mathrm{~N} / \mathrm{mm}^{2}$ up to $30.084 \mathrm{~N} / \mathrm{mm}^{2}$, the wear and RCF damage of both PH steel and BH steel increased. The crack depth and angle of PH steel increased significantly, and the crack growth mechanism changed from intergranular propagation to a mixed mode dominated by intergranular and transgranular growth.

5. The experimental evidence showed that the high-hardness pearlitic rail would still be a good choice under general working conditions $\left(T \gamma / A<30 \mathrm{~N} / \mathrm{mm}^{2}\right)$. For the further development of bainitic rails, it is necessary to consider its microstructure evolution and work hardening during rolling-sliding contact.

\section{Declaration of competing interest}

The authors declare that they have no known competing financial interests or personal relationships that could have appeared to influence the work reported in this paper.

\section{Acknowledgements}

The work was supported by National Natural Science Foundation of China (Nos. 51975489 and 51805446), Autonomous Research Project of State Key Laboratory (No. 2020TPL-T10), Doctoral Innovation Fund Program of Southwest Jiaotong University (No. D-CX201810) and Cultivation Program for the Excellent Doctoral Dissertation of Southwest Jiaotong University.

\section{Appendix A}

Comparison of wear properties between pearlitic and bainitic materials [27,29-37], where B represents bainitic steel and P represents pearlitic steel.

\begin{tabular}{|c|c|c|c|c|c|c|c|c|c|c|c|}
\hline \multirow[t]{2}{*}{ Reference } & \multirow[t]{2}{*}{ Steel } & \multicolumn{5}{|c|}{ Chemical composition (wt\%) } & \multirow{2}{*}{$\begin{array}{l}\text { Hardness/ } \\
\mathrm{HV}\end{array}$} & \multirow{2}{*}{$\begin{array}{l}\mathrm{R}_{\mathrm{m}, \mathrm{min}} / \\
\mathrm{MPa}\end{array}$} & \multirow{2}{*}{$\begin{array}{l}\mathrm{A}_{5}, \\
\min / \%\end{array}$} & \multirow[t]{2}{*}{ Wear test type } & \multirow{2}{*}{$\begin{array}{l}\text { Lower } \\
\text { mass loss }\end{array}$} \\
\hline & & $\mathrm{C}$ & $\mathrm{Si}$ & $\mathrm{Mn}$ & $\mathrm{Cr}$ & $\begin{array}{l}\mathrm{Ni}+\mathrm{Mo} \\
+\mathrm{V}\end{array}$ & & & & & \\
\hline \multirow{4}{*}{$\begin{array}{l}\text { Garnham et al., } \\
1992 \text { [29] }\end{array}$} & B04 (B) & 0.04 & 0.19 & 0.8 & 2.76 & 2.18 & 275 & 924 & 5 & \multirow{4}{*}{$\begin{array}{l}\text { Twin-disc line contact, } \\
3 \%, 500-1800 \mathrm{MPa} \text {, dry }\end{array}$} & \multirow[t]{4}{*}{ B52 } \\
\hline & B20 (B) & 0.20 & 0.16 & 0.67 & 2.29 & 1.95 & 378 & 1235 & 8 & & \\
\hline & B52 (B) & 0.52 & 0.22 & 0.37 & 1.7 & 1.71 & 355 & 1321 & 6 & & \\
\hline & R52 (P) & 0.52 & 0.2 & 1.07 & $<0.01$ & $<0.04$ & 220 & 781 & 11 & & \\
\hline \multirow{3}{*}{$\begin{array}{l}\text { Singh et al., } 2001 \\
\quad \text { [30] }\end{array}$} & A (B) & 0.44 & 0.94 & 0.70 & 1.02 & 0.74 & $342-376$ & 1239 & 15 & \multirow{3}{*}{$\begin{array}{l}\text { Twin-disc line contact, } \\
236 \mathrm{MPa} \text {, dry }\end{array}$} & \multirow[t]{3}{*}{$\mathrm{P}$} \\
\hline & $\mathrm{B}(\mathrm{B})$ & 0.37 & 0.88 & 0.70 & 0.98 & 0.79 & $340-370$ & 1155 & 14 & & \\
\hline & $880(\mathrm{P})$ & 0.70 & 0.31 & 1.16 & 0.034 & 0.005 & $250-278$ & 900 & 15 & & \\
\hline \multirow{2}{*}{$\begin{array}{l}\text { C.C. Vi'afara } \\
\text { et al., } 2005 \\
\text { [31] }\end{array}$} & $\begin{array}{l}\text { AISI } 15 \mathrm{~B} 30 \\
\text { (B) }\end{array}$ & 0.35 & & 1.5 & & & $400-420$ & & & \multirow{2}{*}{$\begin{array}{l}\text { Pin-disc line contact, } \\
\text { sliding wear, } 10 \mathrm{~N} \text {, dry }\end{array}$} & \multirow[t]{2}{*}{$\mathrm{P}$} \\
\hline & $\begin{array}{l}\text { AISI } 1070 \\
\text { (P) }\end{array}$ & $0.65-0.75$ & & $0.6-0.9$ & & & $320-340$ & & & & \\
\hline \multirow{2}{*}{$\begin{array}{l}\text { Lee et al., } 2005 \\
\text { [32] }\end{array}$} & J6 (B) & 0.26 & 1.81 & 2 & 1.93 & & 41.65HRC & & & \multirow{2}{*}{$\begin{array}{l}\text { Ball-disc point contact, } \\
\text { sliding wear, } 10 \mathrm{~N} \text {, dry }\end{array}$} & \multirow[t]{2}{*}{$\mathrm{P}$} \\
\hline & J6 (B) & 0.26 & 1.81 & 2 & 1.93 & & 41.65HRC & & & & \\
\hline \multirow{4}{*}{$\begin{array}{l}\text { Zapata et al., } \\
2011 \text { [33] }\end{array}$} & B320 (B) & 0.35 & 0.17 & 1.46 & & 0.029 & 320 & & & \multirow{4}{*}{$\begin{array}{l}\text { Twin-disc line contact, } \\
470 \mathrm{MPa} \text {, dry }\end{array}$} & \multirow[t]{4}{*}{ B370 } \\
\hline & B370 (B) & 0.35 & 0.17 & 1.46 & & 0.029 & 370 & & & & \\
\hline & P320 (P) & 0.668 & 0.537 & 1.09 & & 0.05 & 320 & & & & \\
\hline & P370 (P) & 0.668 & 0.537 & 1.09 & & 0.05 & 370 & & & & \\
\hline \multirow{4}{*}{$\begin{array}{l}\text { Feng et al., } 2014 \\
\text { [27] }\end{array}$} & S1 (B) & 0.24 & 1.44 & 1.76 & 1.58 & 1.14 & 416 & 1410 & 13 & \multirow{4}{*}{$\begin{array}{l}\text { Pin-disc line contact, } \\
\text { sliding wear, 5- } 40 \mathrm{MPa} \text {, } \\
\text { dry }\end{array}$} & \multirow[t]{4}{*}{ B (S2) } \\
\hline & S2 (B) & 0.24 & 1.44 & 1.76 & 1.58 & 1.14 & 404 & 1370 & 16 & & \\
\hline & S3 (B) & 0.24 & 1.44 & 1.76 & 1.58 & 1.14 & 381 & 1400 & 16 & & \\
\hline & U75V (P) & 0.71 & 0.68 & 0.86 & & 0.09 & 360 & 1230 & 12 & & \\
\hline \multirow{3}{*}{$\begin{array}{r}\text { Hasan et al., } \\
2018 \text { [34] }\end{array}$} & BR1 (B) & 0.2 & 1.25 & 1.3 & 1 & 1.05 & 375 & 1314 & 18 & \multirow{3}{*}{$\begin{array}{l}\text { Twin-disc line contact, } \\
10 \%, 877 \mathrm{MPa} \text {, dry }\end{array}$} & \multirow[t]{3}{*}{ BR2 } \\
\hline & BR2 (B) & 0.23 & 1.45 & 1.5 & 1.2 & 1.2 & 419 & 1586 & 16 & & \\
\hline & $\mathrm{PR}(\mathrm{P})$ & 0.75 & 0.3 & 1.05 & & & 268 & 887 & 11 & & \\
\hline $\begin{array}{l}\text { Liu et al., } 2019 \\
\text { [35] }\end{array}$ & $\begin{array}{l}\text { U78CrVH } \\
\text { (P) }\end{array}$ & $0.75-0.8$ & $0.6-0.8$ & $0.7-0.85$ & $<0.414$ & & 385 & 1366 & 12 & $\begin{array}{l}\text { Twin-disc line contact, } \\
2 \%, 1430 \mathrm{MPa} \text {, dry }\end{array}$ & $\mathrm{P}$ \\
\hline & U75VH (P) & $0.72-0.77$ & $0.5-0.7$ & $0.8-0.9$ & $<0.077$ & & 354 & 1274 & 14.5 & & \\
\hline & $\begin{array}{l}\text { U22SiMn } \\
\text { (B) }\end{array}$ & $0.2-0.26$ & $1.3-1.45$ & $2-2.1$ & $<0.589$ & & 401 & 1283 & 16 & & \\
\hline Chen et al., 2019 & $\mathrm{AB} 1$ (B) & $0.18-0.28$ & $1.5-2.5$ & $0.9-1.9$ & $0.3-1$ & $0.1-0.6$ & 420 & $>1280$ & & & B \\
\hline$[36]$ & U71Mn (P) & $0.65-0.76$ & $0.15-0.35$ & $1-1.4$ & & & 330 & $>880$ & & & \\
\hline
\end{tabular}




\begin{tabular}{|c|c|c|c|c|c|c|c|c|c|c|c|}
\hline \multirow[t]{2}{*}{ Reference } & \multirow[t]{2}{*}{ Steel } & \multicolumn{5}{|c|}{ Chemical composition (wt\%) } & \multirow{2}{*}{$\begin{array}{l}\text { Hardness/ } \\
\text { HV }\end{array}$} & \multirow{2}{*}{$\begin{array}{l}\mathrm{R}_{\mathrm{m}, \min } / \\
\mathrm{MPa}\end{array}$} & \multirow{2}{*}{$\begin{array}{l}\mathrm{A}_{5}, \\
\min / \%\end{array}$} & \multirow[t]{2}{*}{ Wear test type } & \multirow{2}{*}{$\begin{array}{l}\text { Lower } \\
\text { mass loss }\end{array}$} \\
\hline & & $\mathrm{C}$ & $\mathrm{Si}$ & Mn & $\mathrm{Cr}$ & $\begin{array}{l}\mathrm{Ni}+\mathrm{Mo} \\
+\mathrm{V}\end{array}$ & & & & & \\
\hline & & & & & & & & & & $\begin{array}{l}\text { Ring-block contact, } \\
\text { sliding wear, } 600 \mathrm{MPa} \text {, } \\
\text { dry }\end{array}$ & \\
\hline \multirow{2}{*}{$\begin{array}{l}\text { Rezende et al., } \\
2019 \text { [37] }\end{array}$} & Wheel (B) & 0.71 & 0.43 & 0.84 & 0.27 & 0.27 & 457 & 1600 & 11 & Twin-disc point contact, & B \\
\hline & Wheel (P) & 0.71 & 0.43 & 0.84 & 0.27 & 0.27 & 357 & 1103 & 16 & $0.75 \%, 2200 \mathrm{MPa}$, dry & \\
\hline
\end{tabular}

\section{References}

[1] M. Ph Papaelias, C. Roberts, C.L. Davis, A review on non-destructive evaluation of rails: state-of-the-art and future development, Proc. Inst. Mech. Eng. - Part F J. Rail Rapid Transit 222 (4) (2008) 367-384.

[2] Y. Zhu, W. Wang, R. Lewis, W. Yan, S.R. Lewis, H. Ding, A review on wear between railway wheels and rails under environmental conditions, J. Tribol. Trans. ASME 141 (2019) 120801-120813.

[3] X.J. Zhao, J. Guo, Q.Y. Liu, E. Butini, L. Marini, E. Meli, A. Rindi, W.J. Wang, Effect of spherical dents on microstructure evolution and rolling contact fatigue of wheel/ rail materials, Tribol. Int. 127 (2018) 520-532.

[4] G. Girsch, R. Heyder, Advanced Pearlitic and Bainitic High Strength Rails Promise to Improve Rolling Contact Fatigue Resistance, in: 7th World Congress on Railway Research (WCRR2006), Montreal, Canada, 2006.

[5] P. Pointner, High strength rail steels-The importance of material properties in contact mechanics problems, Wear 265 (2008) 1373-1379.

[6] P. Lu, S.R. Lewis, S. Fretwell-Smith, D.L. Engelberg, D.I. Fletcher, R. Lewis, Laser Cladding of Rail; the Effects of Depositing Material on Lower Rail Grades, Wear, 2019, pp. 438-439, 203045.

[7] J.F. Santa, P. Cuervo, P. Christoforou, M. Harmon, A. Beagles, A. Toro, R. Lewis, Twin Disc Assessment of Wear Regime Transitions and Rolling Contact Fatigue in R400HT-E8 Pairs, Wear, 2019, pp. 432-433, 102916.

[8] R. Heyder, K. Maedler, The influence of wheel and rail material on the wear of the respective contact partner, in: Proceedings of CM2015 10th International Conference on Contact Mechanics and Wear of Rail/Wheel Systems, Colorado, USA, 30 August-3 September 2015, 2015.

[9] R. Stock, D.T. Eadie, K. Oldknow, Rail grade selection and friction management: combined approach for optimising rail-wheel contact, Ironmak. Steelmak. 40 (2) (2013) 108-114.

[10] G. Vasic, Modelling of Wear and Crack Initiation in Rails, PhD Thesis, University of Newcastle Upon Tyne, 2013.

[11] R. Heyder, G. Girsch, Testing of HSH rails in high-speed tracks to minimise rail damage, Wear 258 (2005) 1014-1021.

[12] L.C. Guo, W.T. Zhu, L.B. Shi, Q.Y. Liu, Z.B. Cai, W.J. Wang, Study on wear transition mechanism and wear map of CL60 wheel material under dry and wet conditions, Wear 426 (2019) 1771-1780.

[13] W. Zhong, J.J. Hu, P. Shen, C.Y. Wang, Q.Y. Liu, Experimental investigation between rolling contact fatigue and wear of high-speed and heavy-haul railway and selection of rail material, Wear 271 (2011) 2485-2493.

[14] S. Sharma, S. Sangal, K. Mondal, Wear behaviour of bainitic rail and wheel steels, Mater. Sci. Technol. 32 (4) (2016) 266-274.

[15] I. Hlavatý, M. Sigmund, L. Krejčí, P. Mohyla, The bainitic steels for rails applications, Mater. Eng. 16 (4) (2009) 44-50.

[16] P. Clayton, K.J. Sawley, P.J. Bolton, G.M. Pell, Wear behavior of bainitic steels, Wear 120 (1987) 199-220.

[17] D.R. Pendleton, K. Compton, E.G. Jones, Welded and cast-centre crossings accepted after trial, Railw. Gaz. Int. 3 (1986) 176-177.

[18] H.K. Bhadeshia, High Performance Bainitic Steels, Materials Science Forum vols. 500-501, Trans Tech Publications Ltd, 2005, pp. 63-74.

[19] H. Masumoto, K. Sugino, H. Hayashida, Development of Wear Resistant and Antishelling High Strength Rails in Japan, Heavy Haul Railways Conference, Perth, Australia, 1978.

[20] J. Kalousek, D.M. Fegredo, E.E. Laufer, The wear resistance and worn metallography of pearlite, bainite and tempered martensite rail steel microstructures of high hardness, Wear 105 (1985) 199-222.

[21] R. Devanathan, P. Clayton, Rolling sliding wear behavior of three bainitic steels, Wear 151 (1991) 255-267.

[22] P. Clayton, N. Jin, Unlubricated sliding and rolling/sliding wear behavior of continuously cooled low/medium carbon bainitic steels, Wear 200 (1996) 74-82.

[23] X. Su, P. Clayton, Surface-initiated rolling contact fatigue of pearlitic and low carbon bainitic steels, Wear 197 (1-2) (1996) 137-144.

[24] R. Stock, R. Pippan, RCF and wear in theory and practice-the influence of rail grade on wear and RCF, Wear 271 (1-2) (2011) 125-133.

[25] H. Yokoyama, S. Mitao, S. Yamamoto, M. Fujikake, Effect of the angle of attack on flaking behavior in pearlitic and bainitic steel rails, Wear 253 (1-2) (2002) 60-66.

[26] H. Yokoyama, S. Mitao, S. Yamamoto, Y. Kataoka, T. Sugiyama, High Strength Bainitic Steel Rails for Heavy Haul Railways with Superior Damage Resistance, NKK TECHNICAL REPORT-JAPANESE EDITION-, 2000, pp. 17-23.

[27] X.Y. Feng, F.C. Zhang, J. Kang, Z.N. Yang, X.Y. Long, Sliding wear and low cycle fatigue properties of new carbide free bainitic rail steel, Mater. Sci. Technol. 30 (12) (2014) 1410-1418.
[28] F.C. Zhang, C.L. Zheng, B. Lv, T.S. Wang, M. Li, M. Zhang, Effects of Hydrogen on the Properties of Bainitic Steel Crossing, Engineering Failure Analysis, vol. 16, 2009, pp. 1461-1467.

[29] J.E. Garnham, J.H. Beynon, Dry rolling-sliding wear of bainitic and pearlitic steels, Wear 157 (1) (1992) 81-109.

[30] U.P. Singh, B. Roy, S. Jha, S.K. Bhattacharyya, Microstructure and mechanical properties of as rolled high strength bainitic rail steels, Mater. Sci. Technol. 17 (1) (2001) 33-38.

[31] C.C. Viafara, M.I. Castro, J.M. Velez, A. Toro, Unlubricated sliding wear of pearlitic and bainitic steels, Wear 259 (1-6) (2005) 405-411.

[32] K.M. Lee, A.A. Polycarpou, Wear of conventional pearlitic and improved bainitic rail steels, Wear 259 (1-6) (2005) 391-399.

[33] D. Zapata, J. Jaramillo, A. Toro, Rolling contact and adhesive wear of bainitic and pearlitic steels in low load regime, Wear 271 (1-2) (2011) 393-399.

[34] S.M. Hasan, D. Chakrabarti, S.B. Singh, Dry rolling/sliding wear behaviour of pearlitic rail and newly developed carbide-free bainitic rail steels, Wear 408 (2018) $151-159$.

[35] J.P. Liu, Y.Q. Li, Q.Y. Zhou, Y.H. Zhang, Y. Hu, L.B. Shi, W.J. Wang, F.S. Liu, S. B. Zhou, C.H. Tian, New insight into the dry rolling-sliding wear mechanism of carbide-free bainitic and pearlitic steel, Wear $432-433$ (2019), 202943.

[36] Y. Chen, R. Ren, J. Pan, R. Pan, X. Zhao, Microstructure evolution of rail steels under different dry sliding conditions: a comparison between pearlitic and bainitic microstructures, Wear 438 (2019), 203011.

[37] C. Chattopadhyay, S. Sangal, K. Mondal, A. Garg, Improved wear resistance of medium carbon microalloyed bainitic steels, Wear 289 (2012) 168-179.

[38] K.J. Sawley, R. Jimenez, The Comparative Wear of Premium and Bainitic Rail Steels under Heavy Axle Loads vol. 941, Association of American Railroads Research Report R-, 2000.

[39] W.J. Wang, R. Lewis, B. Yang, L.C. Guo, Q.Y. Liu, M.H. Zhu, Wear and damage transitions of wheel and rail materials under various contact conditions, Wear 362363 (2016) 146-152.

[40] H.H. Ding, C.G. He, L. Ma, J. Guo, Q.Y. Liu, W.J. Wang, Wear mapping and transitions in wheel and rail material under different contact pressure and sliding velocity conditions, Wear 352-353 (2016) 1-8.

[41] W.T. Zhu, L.C. Guo, L.B. Shi, Z.B. Cai, Q.L. Li, Q.Y. Liu, W.J. Wang, Wear and damage transitions of two kinds of wheel materials in the rolling-sliding contact, Wear 398-399 (2018) 79-89.

[42] M. Burstow, Wheel/rail Hardness and Total "System" Wear", V/T SIC Report TSPR033-00027 Issue 2, 2014.

[43] M. Benson, Effect of Differential Hardness on Wheel/rail Wear: Literature Survey, BRR Report LR MT 006, 1993.

[44] R. Lewis, P. Christoforou, W.J. Wang, A. Beagles, M. Burstow, S.R. Lewis, Investigation of the influence of rail hardness on the wear of rail and wheel materials under dry conditions (ICRI Wear Mapping Project), Wear 430-431 (2019) 383-392.

[45] X. Hu, P. Van Houtte, M. Liebeherr, A. Walentek, M. Seefeldt, H. Vandekinderen, Modeling work hardening of pearlitic steels by phenomenological and Taylor-type micromechanical models, Acta Mater. 54 (2006) 1029-1040.

[46] S.M. Hasan, A. Mandal, S.B. Singh, D. Chakrabarti, Work hardening behaviour and damage mechanisms in carbide-free bainitic steel during uni-axial tensile deformation, Mater. Sci. Eng., A 751 (2019) 142-153.

[47] A. Kapoor, Wear by plastic ratcheting, Wear 212 (1) (1997) 119-130.

[48] Y. Hu, C.R. Su, L.C. Guo, Q.Y. Liu, J. Guo, Z.R. Zhou, W.J. Wang, Effect of rolling direction on microstructure evolution of CL60 wheel steel, Wear 424-425 (2019) 203-215.

[49] Y. Hu, L. Zhou, H.H. Ding, G.X. Tan, R. Lewis, Q.Y. Liu, J. Guo, W.J. Wang, Investigation on wear and rolling contact fatigue of wheel-rail materials under various wheel/rail hardness ratio and creepage conditions, Tribol. Int. 143 (2020), 106091.

[50] X.L. Gui, K.K. Wang, G.H. Gao, R.D.K. Misra, Z.L. Tan, B.Z. Bai, Rolling contact fatigue of bainitic rail steels: the significance of microstructure, Mater. Sci. Eng., A 657 (2016) 82-85.

[51] L. Ma, C.G. He, X.J. Zhao, J. Guo, Y. Zhu, W.J. Wang, Q.Y. Liu, X.S. Jin, Study on wear and rolling contact fatigue behaviours of wheel-rail materials under different slip ratio conditions, Wear 366-367 (2016) 13-26.

[52] R. Lewis, R.S. Dwyer-Joyce, U. Olofsson, J. Pombo, J. Ambrosio, M. Pereira, N. Kuka, Mapping railway wheel material wear mechanisms and transitions, Proc. Inst. Mech. Eng. - Part F J. Rail Rapid Transit 224 (3) (2010) 125-137. 
[53] R. Lewis, R.S. Dwyer-Joyce, Wear mechanisms and transitions in railway wheel steels, Proc. IMechE, Part J: Eng. Tribol 218 (2004) 467-478.

[54] P.J. Bolton, P. Clayton, Rolling-siding wear damage in rail and tyre steels, Wear 93 (1984) 145-165.
[55] D. Danks, P. Clayton, Comparison of the wear process for eutectoid rail steels: field and laboratory tests, Wear 120 (1987) 233-250. 